\title{
6. Sınıf Görme Engelli Öğrencilere Destek ve Hareket Sistemi Konusundaki Kavramların Öğretimi
}

\author{
Fatih Yazıc1 ${ }^{1}$, Mustafa Sözbilir ${ }^{2}$
}

${ }^{1}$ Matematik ve Fen Bilimleri Anabilim Dal, Eğitim Bilimleri Enstitüsü, Atatürk Üniversitesi, Erzurum, Türkiye ${ }^{2}$ Matematik ve Fen Bilimleri Eğitimi Bölümü, Kazım Karabekir Eğitim Fakültesi, Atatürk Üniversitesi, Erzurum, Türkiye

Sorumlu Yazar: Fatih Yazıc1, fatyaz20@gmail.com

Makale Türü: Araştırma Makalesi

Bilgilendirme: $\mathrm{Bu}$ makale, birinci yazarın ikinci yazarın danışmanlığında tamamladığı doktora tezine dayalı olarak oluşturulmuştur.

Araştırma Desteği: Bu araştırma, TÜBİTAK tarafından (Proje No: 114K725) desteklenmiştir.

Kaynak Gösterimi: Yazıcı, F., \& Sözbilir, M. (2020). 6. sınıf görme engelli öğrencilere destek ve hareket sistemi konusundaki kavramların öğretimi. Eğitimde Kuram ve Uygulama, 16(2), 231-250. doi: 10.17244/eku.799303

\section{Teaching Concepts on Musculoskeletal System to 6th Grade Visually Impaired Students}

\author{
Fatih Yazıc1 ${ }^{1}$, Mustafa Sözbilir ${ }^{2}$
}

${ }^{1}$ Department of Mathematics and Science Education, Graduate School of Educational Sciences, Atatürk University, Erzurum, Turkey

${ }^{2}$ Department of Mathematics and Science Education, Kazım Karabekir Faculty of Education, Atatürk University, Erzurum, Turkey

Corresponding Author: Fatih Yazıc1, fatyaz20@gmail.com

Article Type: Research Article

Acknowledgement: This article was generated based on the first author's master thesis prepared under the guidance of the second author.

Research Funding: This research was supported by TÜBİTAK (Project No: 114K725).

To Cite This Article: Yazıcı, F., \& Sözbilir, M. (2020). 6. sınıf görme engelli öğrencilere destek ve hareket sistemi konusundaki kavramların öğretimi. Eğitimde Kuram ve Uygulama, 16(2), 231-250. doi: 10.17244/eku.799303 


\title{
6. Sınıf Görme Engelli Öğrencilere Destek ve Hareket Sistemi Konusundaki Kavramların Öğretimi
}

\author{
Fatih Yazıc1 ${ }^{1}$, Mustafa Sözbilir ${ }^{2}$
}

${ }^{1}$ Matematik ve Fen Bilimleri Ĕ̌itimi Anabilim Dall, Eğitim Bilimleri Enstitüsü, Atatürk Üniversitesi, Erzurum, Türkiye

${ }^{2}$ Matematik ve Fen Bilimleri Eğitimi Bölümü, Kazım Karabekir Eğitim Fakültesi, Atatürk Üniversitesi, Erzurum, Türkiye

${ }^{1}$ ORCID: http://orcid.org/0000-0002-7901-3132

${ }^{2}$ ORCID: http://orcid.org/0000-0001-6334-9080

\begin{tabular}{|c|c|}
\hline$\ddot{O ̈ z}$ & Makale Bilgisi \\
\hline 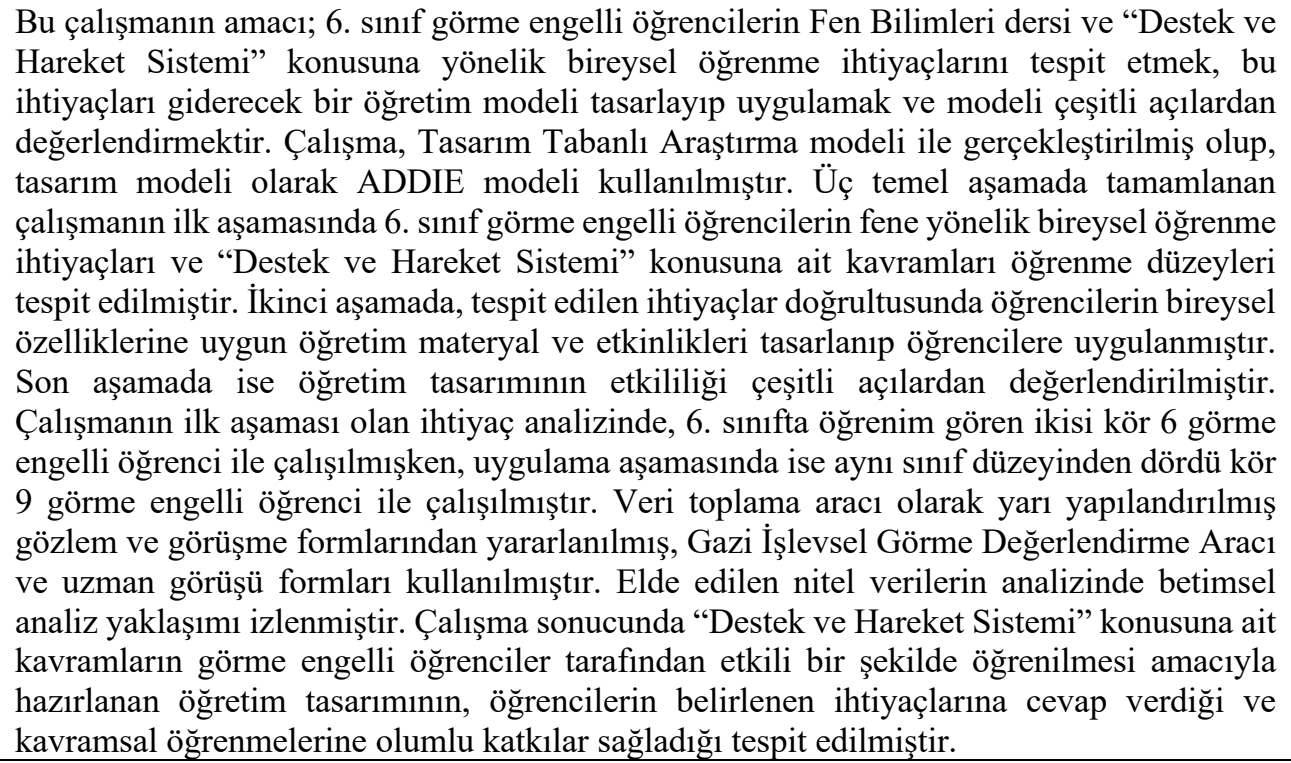 & $\begin{array}{l}\text { Anahtar kelimeler: ADDIE } \\
\text { öğretim tasarımı, Destek ve } \\
\text { hareket sistemi, Görme engelli, } \\
\text { Kavram öğretimi } \\
\text { Makale Geçmişi: } \\
\text { Geliş: } 23 \text { Eylül } 2020 \\
\text { Düzeltme: } 18 \text { Aralık } 2020 \\
\text { Kabul: } 20 \text { Aralık } 2020\end{array}$ \\
\hline
\end{tabular}

Not: Bu çalışmada, veri toplama sürecine geçilmeden Atatürk Üniversitesi Etik Kurulu Başkanlığı’ndan 4.9.2014 tarih ve 05.09 sayılı etik onay alınmıştır. 


\section{Teaching Concepts on Musculoskeletal System to 6th Grade Visually Impaired Students}

\begin{tabular}{|c|c|}
\hline Abstract & Article Info \\
\hline $\begin{array}{l}\text { This study aims to determine the individual learning needs of 6th grade visually impaired } \\
\text { students in Science lessons and Musculoskeletal System, to design and implement a } \\
\text { teaching model that could meet these needs, and to evaluate this model from various aspects. } \\
\text { The study was conducted with the Design-Based Research model, and the ADDIE model } \\
\text { was used as the design model. In the first stage of the study, which was completed in three } \\
\text { basic stages, the individual learning needs of 6th grade visually impaired students and their } \\
\text { learning levels about the concepts of "Musculoskeletal System" were determined. In the } \\
\text { second stage, instructional materials and activities were designed and implemented } \\
\text { following the identified needs and individual characteristics of the students. In the last stage, } \\
\text { the effectiveness of the instructional design was evaluated from various aspects. While } \\
\text { working with six visually impaired students (two of whom were blind) in the first stage } \\
\text { (needs analysis) of the study, it was studied with nine visually impaired students (four of } \\
\text { whom were blind) in the implementation stage. As a data collection tool, semi-structured } \\
\text { observation and interview forms, Gazi Functional Vision Assessment Instrument and expert } \\
\text { opinion forms were used. Descriptive analysis was performed in the analysis of the } \\
\text { qualitative data obtained. As a result of the study, it was determined that the instructional } \\
\text { design, prepared to learn the concepts of "Musculoskeletal System" effectively by visually } \\
\text { impaired students, met the identified needs of the students and made positive contributions } \\
\text { to their concept learning. }\end{array}$ & $\begin{array}{l}\text { Keywords: ADDIE } \\
\text { instructional design, Concept } \\
\text { learning, Musculoskeletal } \\
\text { system, Visually impaired } \\
\text { Article History: } \\
\text { Received: } 23 \text { September } 2020 \\
\text { Revised: } 18 \text { December } 2020 \\
\text { Accepted: } 20 \text { December } 2020 \\
\text { Article Type: Research Article }\end{array}$ \\
\hline
\end{tabular}




\section{Extended Summary}

\section{Introduction}

Considering that most of the information is acquired by using the sense of sight, the concept learning process will be affected negatively by this situation as a result of weakening or complete loss of the sense of sight. In science courses, for concept learning, students should think about the subject, inquire, and make reveal the relationship between the subjects by frequently including experimental implementation. Experiments and activities should be made in the teaching of biology subjects that contain a large number of abstract concepts, and these subjects/concepts should be embody by using various models, diagrams, and concept maps. However, visually impaired students (VIS) who cannot access instructional materials suitable for their individual needs, cannot participate in experiments/activities and cannot observe. Therefore, concepts should be embodied as much as possible by designing activities/materials suitable for the individual characteristics and needs of VIS. In the literature, it was observed that the studies conducted in the field of science teaching for VIS are mostly of situation determination studies and most of them are focused on chemistry subjects. There are few studies on material design/use for teaching biology subjects and concepts to VIS. In particular, there have not been any studies on VIS's levels of learning the concepts of the musculoskeletal system, the difficulties they face, learning needs to be met, and material design. It is expected that this study could contribute to filling the gap in this field, meet the needs of VIS in science learning, and enable effective teaching of the basic concepts of the musculoskeletal system.

The purpose of this study is to determine the needs of 6th-grade VIS for science learning, to design and implement teaching materials/activities that can provide effective learning of the basic concepts of musculoskeletal system considering these needs, and to evaluate the effectiveness of this teaching model. For this purpose, answers to the following research questions were sought.

Regarding the basic concepts of the musculoskeletal system;

1. What are the conceptual learning difficulties of 6th-grade VIS?

2. What are the learning needs of 6th-grade VIS?

3. What should be considered while developing teaching materials?

4. What is the effect of the instructional design developed on concept learning?

5. What are the factors affecting the usefulness of the instructional design developed?

\section{Method}

In this study, which was conducted using the Design-Based Research method, the ADDIE model was used for instructional design, and the study was completed in three main stages. In the first stage, which is the needs analysis, the individual learning needs of VIS about science learning and their understanding levels of the basic concepts about the musculoskeletal system were determined. In the second stage, the design, development and implementation steps of the ADDIE model were followed, and in order to solve the problems and needs identified in the first stage, a teaching model suitable for individual needs was designed and implemented. In the last stage, the usefulness of the implemented model and its effect on concept learning was evaluated.

In the need's analysis stage (2014-2015 academic year), the study group consists of six VIS, two of whom are blind, studying in the 6th grade of the School for the Visually Impaired in Erzurum. In the implementation stage (2015-2016 academic year), there are nine VIS, four of whom are blind, studying at the same school and grade level.

In the semi-structured classroom observations, Science Lesson Observation Form and Science Activity Observation Form were used. In semi-structured interviews, individual teacher/student interview forms and focus group student discussion forms were made use of. Moreover, Gazi Functional Vision Assessment Instrument was used to determine how and to what extent students use their residual vision in their academic skills. Besides, the Teacher Guide Expert Opinion Form was used so that the experts could evaluate the developed teacher's guide scientifically/formally. The descriptive analysis approach was followed in the analysis of the data obtained.

\section{Results and Discussion}

In the study, VIS's level of understanding of the basic concepts on the musculoskeletal system was determined, and the difficulties and individual learning needs they had in science learning were revealed. Then, a teaching model that can meet the needs of VIS and improve concept learning was designed and implemented. Finally, it was evaluated that this design model can be useful, practical, and may contribute to concept learning.

According to the interviews/observations made, it was determined that there is a need for teaching materials that are suitable for the individual needs of the students, and that can enable the use of other senses as well as sight. However, in the teaching of science concepts, taking into account the vision levels and individual learning needs of VIS, activities/materials containing vivid/contrasting colors should be designed for students with low vision. Also, for blind students, activities/materials that they can use their senses other than sight should be designed. Moreover, using auditory/tactile tools and assistive technologies can contribute to the development of VIS' concept learning. In this sense, 
to teach VIS the subject of the musculoskeletal system, materials and activities have been designed/adapted taking their individual needs into consideration. Through materials prepared for blind students, students were enabled to obtain information by using their senses other than sight. However, students with low vision were given materials consisting of vivid/contrasting colors that they could observe using their current vision levels. Besides, the texts on the knowledge sheets prepared for the blind students were printed in Braille and the drawings/diagrams were simplified and embossed. Instead of printing directly in Braille, the tables in knowledge sheets were first translated into prose and then printed out in Braille so that they can be more easily understood by blind students. Tables and texts were enlarged for students with low vision, while printed materials containing drawings/diagrams were prepared in large scale and using $\mathrm{vivid} /$ contrasting colors. In the concept learning process, among the materials designed for blind students, firstly relief drawings on a two-dimensional plane, and then 3D models of these drawings were used. Finally, real objects are used. Thus, a hierarchy was followed from the least detailed materials to the most detailed ones. However, some students were disturbed by the real bone organs and did not want to examine them because of their extreme sensitivity to odors. For such cases, it is considered appropriate to use 3D models instead of real objects.

As a result of the study, the implementation group students gave more correct answers to the interview questions than the students in the needs analysis group, and the percentage of correct answers given to each interview question in the implementation group was significantly higher than the needs analysis group. It was observed that the materials used made the lessons interesting and entertaining by embodying the abstract concepts and these materials made positive contributions to concept learning. Despite the visual disability, it was concluded that if various adaptations were made in the teaching materials and activities following the individual needs and disability levels of the students, many negativities in the learning process could be eliminated and concepts could be learned effectively by students. 


\section{Giriş}

Görme engeli; çocukluktan itibaren bilişsel ve sosyal gelişimi olumsuz etkileyen, öğrenme becerilerinin kazanılmasını ve kişilerin aktivitelerini etkileyerek kişisel yeteneklerin gelişimini güçleştiren bir engeldir (Bailey \& Wning, 1994). Zihindeki bilgilerin \%80-85'i görme duyusu kullanılarak edinildiğinden, bu duyuda yaşanan bozukluklar öğrenme sürecini ve günlük yaşamı olumsuz etkilemektedir (Cavkaytar \& Diken, 2012). Görme engelli öğrenciler (GEÖ), öğrenme deneyiminin alanı ve çeşitliliği konusunda; fiziksel çevreyle etkileşim, kişiler arası etkileşim, gözlemle ya da diğerlerini model alma yoluyla öğrenme alanlarında kısıtlı bir deneyime sahiptir. Bu kısıtlama onların motor, sosyal, kavramsal, dil, yönelim ve hareket ile öz bakım becerileri gibi alanlarda gören akranlarına göre daha az gelişim göstermesine neden olabilmektedir (Mann, 2006; Silberman \& Erin, 2007; Şafak, 2010).

Fen Bilimleri derslerinde kavram öğretimi için sıklıkla deneysel uygulamalara yer verilerek öğrencileri konu üzerinde düşündürmek, sorgulama yaptırmak, konunun başka konularla ilişkisini ortaya koymalarını sağlamak son derece önemlidir (Saygın, Atılboz, \& Salman, 2006). Fen derslerinde yer alan ve çok sayıda soyut kavram içeren biyoloji konularının öğretiminde de deney ve etkinliklere ağırlık verilmeli, öğrenme güçlüğü çekilen konu ve kavramlar çeşitli modeller, diyagramlar, kavram haritaları vb. aracılığıyla somutlaştırılarak anlaşılır hale getirilmelidir. Deneysel uygulamalar ve görsel etkinlikler aracılığıyla gerçekleştirilen biyoloji eğitiminin, öğrenciler tarafından kavranması güç olan soyut bilgilerin somutlaştırılmasına, öğrencilerin el becerileri ve muhakeme yeteneklerinin geliştirilmesine ve kavramsal öğrenmeye katkı sağlayacağı bilinmektedir (Erten, 1993). Ancak yapılan çalışmalarda; çoğu öğrencinin etkinlik/deney yapabilecekleri ders araç-gereçleri ve somut materyallere/modellere ulaşamamaları, laboratuvarların hem fiziksel hem de uygulama yapma yönünden yetersiz olması nedeniyle biyoloji konularını öğrenmede güçlük çektikleri ve birçok kavram yanılgısı geliştirdikleri belirlenmiştir (Akaydın, Güler, \& Mülayim 2000; Aydın \& Balım, 2009; Bahar, 2002; Çepni, Akdeniz, \& Ayas, 1995; Halim, Finkenstaedt-Quinn, Olsen, Gere, \& Shultz, 2018; Kaya, 2001; Özay-Köse \& Gül, 2016; Öztaş \& Özay, 2004).

Biyoloji konularının öğretimi ve kavram yanılgılarının tespiti ile ilgili çalışmalardan hareketle; herhangi bir görme sorunu yaşamayan öğrencilerin karşılaştıkları fazlaca güçlük mevcutken, görme duyularını kısmen ya da tamamen yitirmiş GEÖ bu alanda gören akranlarına göre çok daha dezavantajı durumdadır (Fraser \& Maguvhe, 2008; Yazıcı \& Sözbilir, 2020). Normal düzeyde gören öğrenciler, görme duyularını kullanarak gözlem yapabilecekleri, deney ve etkinlikleri gerçekleştirebilecekleri ders materyallerine sınırlı da olsa ulaşabilirken, GEÖ bu materyallerden yararlanamadığı gibi, ihtiyaçlarına uygun özel olarak tasarlanmış materyallerle de hemen hemen hiç karşılaşmamaktadır (Sözbilir vd., 2016; Zorluoğlu \& Sözbilir, 2017). Yaşanan bu sorunların giderilebilmesi için GEÖ’in bireysel özellik ve ihtiyaçlarına cevap verebilecek öğretim teknik ve stratejileri seçilmeli, bunlara uygun olarak tasarlanmış etkinlik ve materyaller kullanılarak kavramların mümkün olduğunca somutlaştııılarak öğretilmesi yoluna gidilmelidir (Cavkaytar \& Diken, 2012; Dion, Hoffman, \& Matter, 2000; Ediyanto \& Kawai, 2019; Sözbilir, 2016). GEÖ'e yönelik materyal tasarımında, öğrencilerin tespit edilen bireysel öğrenme ihtiyaçları ve görme düzeylerine uygun materyaller sıfırdan tasarlanmalı ya da normal gören öğrenciler için kullanılan fen dersi materyallerinde yazı puntosunu büyütme, Braille ekleme, kabartma oluşturma, renk zıtlı̆̆ 1 yaratma gibi uyarlamalar yapılmalıdır (Willings, 2020).

Alanyazına bakıldığında GEÖ’e fen öğretimi alanında yapılan çalışmaların çok az bir kısmının doğrudan uygulamaya yönelik yapıldığ inceleme/geliştirme/etkinliği ölçme çalışmalarının en yaygın çalışmalar arasında yer aldığı görülmektedir (Sözbilir vd., 2015). Ancak GEÖ’lere fen öğretimi alanında yapılan çalışmaların büyük kısmı kimya konularında yoğunlaşmaktadır. Bu çalışmalarda sıklıkla GEÖ'e görme dışındaki çeşitli duyuların kullanımı yoluyla kimya kavramlarının öğretimi amaçlanmıştır (Harshman, Bretz, \& Yezierski, 2013; Hiemenz \& Pfeiffer, 1972; Micklos-Lewis \& Bodner, 2013; Poon \& Ovadia, 2008). Ayrıca bazılarında GEÖ'in genel kimya laboratuvarlarında daha aktif olabilmeleri için kullanılan öğretim tekniklerinde yapılan uyarlamalar (Boyd-Kimball, 2012; Lunsford \& Bargerhuff, 2006; Neely, 2007; Ratliff, 1997) ve materyal tasarım 1 (Gupta \& Singh, 1998; Supalo, 2005; Supalo, Mallouk, Rankel, Amorosi, \& Graybill, 2008) konuları çalışılmıştır.

Fen öğretiminde kimya konuları odağında yapılan çalışmaların dışında GEÖ’e biyoloji konu ve kavramlarının öğretimi amacıyla yapılan materyal tasarımı ve kullanımı çalışmaları son derece azdır (Cooperman, 1980; Fraser \& Maguvhe, 2008; Sözbilir, Yazıcı, \& Gül, 2018). Cooperman (1980) tarafından yapılan en kapsamlı çalışmada, GEÖ için elle tutulur somut modeller, iki boyutlu kabartma çizimler, az görenlerin görsel, körlerin ise işitsel olarak yararlandığ videolar kullanılmış, öğrencilerle birlikte araştırma gezileri düzenlenerek öğrencilere görme duyusu dışındaki diğer tüm duyuları kullandırılarak biyoloji kavramlarının öğretimi amaçlanmıştır. Çalışmada sözü edilen biyoloji kavramları; hücre, hücre bölünmesi, genetik, beslenme, üreme, dolaşım ve iskelet sistemi konularıyla ilgilidir. Ancak bu çalışma dışında GEÖ'in destek ve hareket sistemi konusuna ait kavramları öğrenebilme düzeyleri, karşılaştıkları güçlükler, giderilmesi gereken öğrenme ihtiyaçları ve materyal tasarımıyla ilgili yapılmış herhangi bir çalışmaya rastlanmamıştır. Hâlbuki destek ve hareket sistemi konusunda sahip olunan bilgiler öğrencilerin özellikle günlük hayatta sağlıklı yaşam, beslenme ve spor alışkanlıklarını yakından ilgilendireceği, bu alandaki yaşadıkları öğrenme eksikliklerinin ise destek ve hareket sistemi sağlığını korumalarına engel olacağı ve birçok sağlık sorunuyla karşı karşıya kalmalarına yol açacağı düşünülmektedir. Yapılan bu çalışmanın alandaki boşluğu doldurmaya katkı sağlaması, GEÖ'in fen öğrenimindeki 
ihtiyaçlarını karşılaması ve "Destek ve Hareket Sistemi” konusundaki temel kavramların etkili bir şekilde öğretimine imkân vermesi beklenmektedir.

\section{Çalışmanın Amacı}

Bu çalışmanın amacı; 6. sınıf GEÖ'in fen öğrenimine yönelik ihtiyaçlarını tespit etmek, bu ihtiyaçları göz önünde bulundurarak "Destek ve Hareket Sistemi” konusundaki temel kavramların etkili öğrenimini sağlayacak öğretim materyalleri/etkinlikleri tasarlayıp öğrencilere uygulamak ve bu tasarım modelinin etkililiğini değerlendirmektir. $\mathrm{Bu}$ amaç doğrultusunda aşağıdaki araştırma sorularına cevap aranmıştır.

\section{Araştırma Problemleri}

6. sınıf GEÖ'in "Destek ve Hareket Sistemi” konusunda yer alan temel kavramlara yönelik;

1. Kavramsal öğrenme güçlükleri nelerdir?

2. Öğrenme ihtiyaçları nelerdir?

3. Öğretim materyalleri geliştirilirken nelere dikkat edilmelidir?

4. Geliştirilen öğretim tasarımının kavram öğrenimine etkisi nedir?

5. Geliştirilen öğretim tasarımının kullanışlılığını etkileyen unsurlar nelerdir?

\section{Araştırma Modeli}

\section{Yöntem}

Tasarım Tabanlı Araştırma yöntemi kullanılarak gerçekleştirilen bu çalışmada öğretim tasarımı amacıyla ADDIE modeli kullanılmış ve çalışma üç ana aşamada tamamlanmıştır. Tasarım tabanlı araştırma; analiz, tasarım, geliştirme, uygulama, değerlendirme ve tekrar değerlendirme süreçlerinin sürekli bir döngü içinde olduğu, araştırmacının öğretmeöğrenme etkinliklerine bizzat etkin katıldığı, öğretme-öğrenme konuları ile ilgili kuram-tasarım-uygulama ilişkisinin ortaya çıkartılarak daha verimli bir öğretimin oluşturulduğu araştırma yöntemidir (Kelly, 2003; Kuzu, Çankaya, \& Misırl1, 2011; Wang \& Hannafin, 2005). İlk aşama olan ihtiyaç analizinde GEÖ’in fen öğrenimi konusundaki bireysel öğrenme ihtiyaçları ile "Destek ve Hareket Sistemi" konusundaki temel kavramları anlama düzeyleri belirlenmiştir. İkinci aşamada ADDIE modelinin tasarım, geliştirme ve uygulama basamakları izlenmiş olup, birinci aşamada tespit edilen sorun ve ihtiyaçları gidermek amacıyla bireysel ihtiyaçlara uygun öğretim modeli tasarlanmış ve uygulanmıştır. Son aşamada ise uygulanan öğretim modelinin kullanışl1lığ 1 ve kavram öğrenimine etkisi değerlendirilmiştir. Bu çalışmada, veri toplama sürecine geçilmeden Atatürk Üniversitesi Etik Kurulu Başkanlığı'ndan 4.9.2014 tarih ve 05.09 sayılı etik onay alınmıştır.

\section{Çalışma Grubu}

Araştırmada iki ayrı çalışma grubu bulunmaktadır. İhtiyaç analizi aşamasındaki çalışma grubu, 2014-2015 eğitimöğretim yılında Erzurum şehir merkezinde bulunan Görme Engelliler Ortaokulu'nun 6. sınıfında öğrenim gören ikisi kör toplam altı GEÖ'den oluşmaktadır. Uygulama aşamasındaki çalışma grubunda ise 2015-2016 eğitim-öğretim y1lında aynı okul ve sınıf düzeyinde öğrenim gören dördü kör toplam dokuz GEÖ bulunmaktadır (Tablo 1). Çalışma grubu amaçlı örnekleme yöntemi kullanılarak oluşturulmuştur. Nicel araştırmalarla karşılaştırıldığında nitel araştırmalarda daha küçük gruplarla çalışıldığı ve genelleme yapma amaçlanmadığından araştırılan konuyu en iyi yansıtacak zengin ve derinlemesine bilgi içeren durumların seçiminde amaçlı örnekleme yöntemi tercih edilir (Patton, 2002).

Tablo 1. Çalışma grubu öğrencilerinin özellikleri

\begin{tabular}{ccc}
\hline & İhtiyaç analizi grubu $(2014-2015)$ \\
\hline Öğrenciler & Cinsiyet & Görme düzeyi \\
\hline$\ddot{O}_{\mathrm{i} .1}$ & $\mathrm{~K} 1 \mathrm{z}$ & Az gören \\
$\ddot{O}_{\mathrm{i} .2}$ & Erkek & Kör \\
Ö$_{\mathrm{i} .3}$ & $\mathrm{~K} 1 \mathrm{z}$ & $\mathrm{Kör}$ \\
$\ddot{O}_{\mathrm{i} .4}$ & $\mathrm{~K} 1 \mathrm{z}$ & Az gören \\
$\ddot{O}_{\mathrm{i} .5}$ & $\mathrm{~K} 1 \mathrm{z}$ & Az gören \\
$\ddot{O}_{\mathrm{i} .6}$ & Erkek & Az gören
\end{tabular}

\begin{tabular}{|c|c|c|}
\hline \multicolumn{3}{|c|}{ Uygulama grubu (2015-2016) } \\
\hline Öğrenciler & Cinsiyet & Görme düzeyi \\
\hline$\ddot{O}_{\mathrm{U} .1}$ & Erkek & Az gören \\
\hline$\ddot{O}_{\mathrm{U} .2}$ & Erkek & Az gören \\
\hline ÖU. 3 & Erkek & Az gören \\
\hline$\ddot{O}_{\mathrm{U} .4}$ & $\mathrm{~K} 1 \mathrm{Z}$ & Az gören \\
\hline$\ddot{O}_{\mathrm{U} .5}$ & Erkek & Kör \\
\hline$\ddot{O}_{\mathrm{U} .6}$ & $\mathrm{~K}_{1 \mathrm{Z}}$ & Kör \\
\hline$\ddot{O}_{\mathrm{U} .7}$ & Erkek & Az gören \\
\hline$\ddot{O}_{\mathrm{U} .8}$ & Erkek & Kör \\
\hline$\ddot{O ̈}_{\mathrm{U} .9}$ & $\mathrm{~K} 1 \mathrm{z}$ & Kör \\
\hline
\end{tabular}

\section{Veri Toplama Araçları}

Gerçekleştirilen yarı-yapılandırılmış sınıf içi gözlemlerde, öğrencilerin fen öğrenimine yönelik bireysel öğrenme ihtiyaçları ve karşılaştıkları sorunları tespit etmek amacıyla ihtiyaç analizi aşamasında Fen Dersi Gözlem Formu (FDGF), uygulama/değerlendirme aşamalarında ise tasarlanıp uygulanan öğretim modelinin çeşitli açılardan değerlendirilmesi amacıyla Fen Etkinlik Gözlem Formu (FEGF) kullanılmıştır. Her iki gözlem formu da araştırmacılar 
tarafindan uzman görüşleri alınarak ve pilot uygulamaları yapılarak oluşturulmuştur. İhtiyaç analizi aşamasında yapılan yarı yapılandırılmış görüşmelerde fen öğrenimi sürecinde yaşanan sorunlar ve ihtiyaçları belirlemek amacıyla bireysel öğretmen görüşme formu ile odak grup öğrenci görüşme formu kullanılmıştır. Ayrıca işlenen konuyla ilgili kavramsal sorular içeren ve sözlü sınav şeklinde uygulanan bireysel öğrenci görüşme formu öğrencilerin konuyla ilgili kavramsal öğrenme düzeylerini belirlemek amacıyla kullanılmıştır. Uygulama/değerlendirme aşamalarında ise öğretmen ve öğrencilerin gerçekleştirilen öğretime ilişkin görüş ve değerlendirmelerini almak amaciyla bireysel öğretmen görüşme formu ile odak grup öğrenci görüşme formu kullanılmıştır. Ayrıca öğrencilerin uygulanan tasarımın ardından konuya ilişkin kavramsal öğrenme düzeylerini tespit etmek için kavramsal sorulardan oluşan ve sözlü sınav şeklinde uygulanan bireysel öğrenci görüşme formu kullanılmıştır. Araştırma boyunca gerçekleştirilen görüşmelerde kullanılan tüm görüşme formları yine araştırmacılar tarafından alanyazından ve uzman görüşlerinden yararlanılarak oluşturulmuştur. $\mathrm{Bu}$ veri toplama araçları dışında öğrencilerin görme düzeyleri ve bireysel ihtiyaçlarına uygun bir öğretim modeli tasarlayabilmek için öğrencilerin mevcut görme kalıntılarını akademik becerilerinde nasıl ve ne kadar kullandıklarını belirleyebilmek amacıyla Gazi İşlevsel Görme Değerlendirme Aracı'ndan (GİGDA) yararlanılmıştır (Şafak, Çakmak, Kan, \& O'Dwyer, 2013). Yine uygulama aşamasında kullanılmak üzere geliştirilen öğretmen kılavuzunun uzmanlar tarafından bilimsel/biçimsel açıdan değerlendirilebilmesi için araştırmacılar tarafından tasarlanan Öğretmen Kılavuzu Uzman Görüşü Formu (ÖKUGF) kullanılmıştır.

\section{Veri Analizi}

$\mathrm{Bu}$ çalışmada elde edilen verilerin analizinde betimsel analiz yaklaşımı izlenmiştir. FDGF ve FEGF kullanılarak gerçekleştirilen sınıf içi gözlem verileri ilgili formlara işlenmiş ve tüm süreç video kaydına alınmıştır. Ardından video görüntüleri tekrar izlenerek bir kez daha gözlem yapılmış ve elde edilen veriler ilgili formlara ikinci kez işlenmiştir. Bunun yanı sıra video kameradan seçilen rastgele kayıtlar uzman bir kişi tarafından gözlem formu aracıllğıyla gözlenmiştir. Araştırmacının sınıf ortamında yaptığı gözlemler ile sonrasında video kayıtları üzerinden yaptığ1 gözlemler ve yine uzman tarafından yapılan gözlemler birbiriyle karşılaştırılarak aradaki uyuma bakılmıştır. Bu süreçte ortaya çıkan küçük farklılıklar tartışılarak giderilmiş ve gözlem sonuçlarının analiz süreci tamamlanmıştır. Yarıyapılandırılmış görüşmeler ise kayıt altına alınmış, ardından transkript edilmiş ve analizleri yapılmıştır. Sözlü sınav şeklinde uygulanan bireysel öğrenci görüşmelerinden elde edilen verilerin analizinde ise cevaplar; doğru, kısmen doğru ve yanlış cevap olmak üzere üç gruba ayrılarak analiz edilmiştir. Yapılan görüşmelere ait rastgele seçilen transkriptler uzman bir kişi tarafından da analiz edilerek, bu analizler araştırmacının analizleri ile karşılaştırılmış ve aradaki küçük uyumsuzluklar giderilerek görüşme verilerinin analizi tamamlanmıştır. Bu süreçte ortaya çıkan uyumsuzlukların giderilmesi amacıyla sistematik olarak verilere geri dönülmüş, her bir kişinin kodlarının ne anlama geldiği tartışılarak açıklığa kavuşturulmuş ve birlikte kodlanmıştır.

\section{İhtiyaç Analizi Aşaması}

\section{Bulgular}

Çalışmanın ihtiyaç analizi aşamasından elde edilen verilere göre 6. Sınıf GEÖ'in fen öğrenimi sürecinde karşılanması gereken çeşitli öğrenme ihtiyaçlarının olduğu belirlenmiş ve bu ihtiyaçlar genel olarak öğretim süreci, öğrenci, öğretim materyalleri ve öğretmen ihtiyaçları olmak üzere dört grupta toplanmıştır.

Yapılan görüşmelerde öğrenciler fen derslerini faydalı bir ders olarak görmekte fakat bu derslerde görsel içeriğin fazla olmasının işlerini zorlaştırdığını düşünmektedirler. Öğrenciler konularda yer alan kavramların ne anlama geldiklerini öğrenmek yerine genellikle ezberlemeye çalışmaktadırlar. Dersler daha çok öğretmenin aktif olduğu bir anlayışla yürütülmektedir. Öğrencilerin derse katılımı istenilen düzeyde değildir ve derste tek yönlü anlatıma ağırlık verilmektedir. Öğrencilerin ders içinde birbirleriyle etkileşimi oldukça azdır, birlikte çalışabilecekleri, etkinlik/deney yapabilecekleri imkânlar oluşturulamamaktadır. Öğrenciler; fen dersleri anlatılırken konuların bir defa anlatılıp geçilmesini değil, özellikle anlaşılması zor olan bölümlerin tane tane anlatılarak birkaç kez tekrarlanmasını, az görenler konuların şekiller üzerinde anlatılmasını, körler ise çeşitli modeller kullanılarak konuların somutlaştırılmasını istemektedirler. Öğrencilerin konuyla ilgili görüşleri şöyledir;

Öi.s: "maketler onları parçalayıp verdiklerinde zaten nasıl bi şekli olduğunu, böyle büktüğünde nasıll bi şekil almış anlayabilir hocam."

Öi.s: "Her ders yani o üniteyi böyle büyüterek çekip verseler. ...Biraz daha büyüterek fotokopiyle çektirip verseler, biz de hani okumuş oluruz. Tekrar da edebilirim. Hocamız biraz daha net ve böyle şekille anlatırsa hani bi de üzerinde bunu iki üç kere tekrar edip bize tekrar söylese"

"Destek ve Hareket Sistemi" konusuyla ilgili öğretim programında yer alan kazanımlar ve konu içeriği dikkate alınarak hazırlanan sorulara öğrencilerin vermiş oldukları cevaplar Tablo 2'de belirtilmiştir. Tablo 2'ye göre ihtiyaç analizi grubunda tüm sorulara tam doğru cevap verebilen herhangi bir öğrenci bulunmazken, en yüksek başar1 \%84 düzeyinde kalmıştır (Ö..4). Ö..2 ise hiçbir soruya doğru cevap verememiştir. Soru bazında bakıldığında 4. soru en yüksek 
oranda (\%75) doğru cevaplanmışken, soru 5a, 8 ve 12'ye ise en düşük oranda (\%17) cevap verilmiştir. Ayrıca ihtiyaç analizi grubunun ortalama başarı düzeyi \% 40 'tır (Tablo 2 ).

Tablo 2. Destek ve hareket sistemi konusuna ilişkin soruların cevaplanma durumları

\begin{tabular}{|c|c|c|c|c|c|c|c|c|}
\hline Konu & Sorular & $\ddot{O}_{\mathrm{i} .1}$ & $\ddot{O}_{\mathrm{i} .2}$ & $\ddot{O ̈}_{\mathrm{i} .3}$ & $\ddot{O ̈}_{\mathrm{i} .4}$ & $\ddot{O}_{\mathrm{i} .5}$ & $\ddot{O ̈}_{\mathrm{i} .6}$ & $\%$ \\
\hline \multirow{20}{*}{ 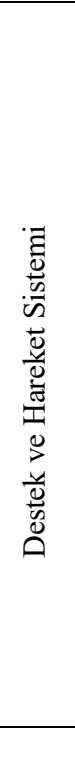 } & 1. Destek ve hareket sistemi ne demektir? Ne işe yarar? & + & - & - & + & - & - & 50 \\
\hline & 2. Destek ve hareket sistemi nelerden oluşur? & + & - & - & + & • & - & 50 \\
\hline & 3. İskelet ne demektir? Ne işe yarar? & + & - & • & - & • & • & 50 \\
\hline & 4. Kemik çeşitleri nelerdir? & + & - & + & + & - & + & 75 \\
\hline & 4a. Kemik çeşitlerine örnek verebilir misin? & + & - & + & + & - & + & 67 \\
\hline & 5. Kemiğin yapısında neler bulunur? & + & - & - & • & - & - & 25 \\
\hline & 5a. Kemikte bulunan yapıların görevleri nelerdir? & • & - & - & - & - & - & 17 \\
\hline & 6. Eklem ne demektir? Ne işe yarar? & + & - & - & + & • & - & 42 \\
\hline & 7. Kaç çeşit eklem vardır? & + & - & - & + & - & + & 50 \\
\hline & 7a. Eklem çeşitlerine örnek verebilir misin? & • & - & - & - & - & • & 25 \\
\hline & 8. Eklem sıvısı ve eklem bağı ne demektir? Ne işe yarar? & • & - & - & • & - & - & 17 \\
\hline & 9. Kas ne demektir? Ne işe yarar? & + & - & - & + & • & - & 42 \\
\hline & 10. Kaç çeşit kas vardır? & + & - & - & + & + & • & 58 \\
\hline & 10a. Kas çeşitlerine örnek verebilir misin? & + & - & - & + & • & - & 42 \\
\hline & $\begin{array}{l}\text { 11. Kasın kasılması ve gevşemesi ne demektir? Bu durumda kaslarda ne tür değişmeler } \\
\text { olur? }\end{array}$ & - & - & - & - & + & - & 42 \\
\hline & 12. Zit çalışan kaslar ne demektir? Örnek verebilir misin? & - & - & - & + & - & - & 17 \\
\hline & 13. Destek ve hareket sistemi hastalıklarına örnek verebilir & $\bullet$ & - & - & + & • & - & 33 \\
\hline & 14. Destek ve hareket sistemi hastalıklarına karşı hangi tedaviler uyg & • & - & - & + & • & - & 33 \\
\hline & 15. Destek ve hareket sistemi sağlığını korumak için nelere dikkat etmeliyiz? & - & - & - & + & - & - & 33 \\
\hline & $\%$ & 76 & 0 & 18 & 84 & 34 & 29 & \\
\hline
\end{tabular}

*Doğru cevap (+, 2 puan), kısmen doğru cevap $(\cdot, 1$ puan), yanlış cevap (-, 0 puan)

Yapılan sınıf içi gözlem ve görüşmelerden "Destek ve Hareket Sistemi” konusuna ait kazanımların ihtiyaç analizi grubu öğrencileri tarafından öğrenilme düzeyleri tespit edilmeye çalışılmıştır. Öncelikle ilgili kazanımların Bloom Taksonomisine göre hangi düzeyde oldukları belirlenmiş, ardından öğrencilerin bu kazanımları ne düzeyde kazandıkları tespit edilerek aradaki fark ihtiyaç olarak ortaya çıkarılmıştır. Tablo 3'de "Destek ve Hareket Sistemi" konusuna ait iki kazanımın Bloom taksonomisine göre hangi düzeyde oldukları ve bu kazanımların öğrenciler tarafından ne ölçüde kazanılabildiği görülmektedir. Buna göre; Ö..4 her iki kazanıma da ulaşmışken, Ö.1. sadece bir kazanıma ulaşabilmiştir. Diğer dört öğrenci ise konuyla ilgili hiçbir kazanıma ulaşamamıştır. Ayrıca sınıf genelinde iki kazanımdan ilki \%33, ikincisi \%17 oranında kazanılabilmiştir (Tablo 3).

Tablo 3. Destek ve hareket sistemi konusuna ait kazanımlara ulaşılma durumları

\begin{tabular}{|c|c|c|c|c|c|c|c|c|c|}
\hline \multirow[b]{2}{*}{ Kazanımlar } & \multicolumn{2}{|c|}{ Düzey } & \multirow[b]{2}{*}{$\ddot{\mathrm{O}}_{\mathrm{I} .1}$} & \multirow[b]{2}{*}{$\ddot{\mathrm{O}}_{\mathrm{I} .2}$} & \multirow[b]{2}{*}{$\ddot{\mathrm{O}}_{\mathrm{i} .3}$} & \multirow[b]{2}{*}{$\ddot{\mathrm{O}}_{\mathrm{I} .4}$} & \multirow[b]{2}{*}{$\ddot{\mathrm{O}}_{\mathrm{i} .5}$} & \multirow[b]{2}{*}{$\ddot{O}_{\mathrm{I} .6}$} & \multirow[b]{2}{*}{$\%$} \\
\hline & $\begin{array}{c}\text { Bilgi } \\
\text { Birikimi }\end{array}$ & $\begin{array}{l}\text { Bilişsel } \\
\text { Süreç }\end{array}$ & & & & & & & \\
\hline $\begin{array}{l}\text { 1. Destek ve hareket sistemine ait yapıları açıklar ve görevlerini } \\
\text { belirterek örnekler verir. }\end{array}$ & Kavramsal & Anlama & + & - & - & + & - & - & 33 \\
\hline $\begin{array}{l}\text { 2. Destek ve hareket sisteminin sağlığını korumak için yapılması } \\
\text { gerekenleri arastırır ve sunar. }\end{array}$ & İşlemsel & Anlama & - & - & - & + & - & - & 17 \\
\hline$\%$ & & & 50 & 0 & 0 & 100 & 0 & 0 & \\
\hline
\end{tabular}

\footnotetext{
*Kazanım kazanılmış (+), kazanım kazanılmamış ya da kısmen kazanılmış (-)
}

Sınıf içi gözlemler ve görüşmeler neticesinde, işlenen konularla ilgili öğrencilerin bireysel özelliklerine uygun somut modellere gereksinim duyulduğu ortaya çıkarılmıştır. Az gören öğrenciler için kitaptaki ilgili bölümlerin büyütülerek renkli fotokopilerinin çekilmesi, kör öğrenciler için yazı ve şekillerde dokunsal özellikler oluşturulmasının yararlı olacağı düşünülmektedir. Konu hakkında öğretmen ve öğrenci görüşleri aşağı da verilmiştir;

Öğretmen: "Materyal yok, malzeme eksik, var olan malzemeler zaten öğrencinin ihtiyacını karşılamıyor. Deney yapacaksin ee bir malzeme var iki malzeme yok"

Öi.1: "Mesela biz kabartma okumaya çalışıoruz, küçük yazıyı okumadığımızı biliyorsunuz. Ama kabartmada resimler yok. Mesela sistemlerle ilgili resimlerin büyütülmüş renkli fotokopileri verilse biz sistemleri oluşturan organların yerlerini, şekillerini, biçimlerini daha iyi kavrarı."”

Görüşme yapılan öğretmenlerin en önemli isteği, çeşitli konularda hizmet içi eğitimler alarak görme engeli ve ek engelleri bulunabilen öğrencilerin eğitim-öğretim ihtiyaçlarını karşılayabilmektir. Ayrıca öğretmenler hizmet içi eğitimler yoluyla Braille alfabeyi de öğrenerek öğrencilerin yazdıklarını okumayı ve anında dönüt vermeyi, bireysel 
ihtiyaçları ve görme düzeylerine uygun etkinlik ve materyaller tasarlama becerisi kazanabilmeyi arzu etmektedirler. Öğretmenlerin bu konuda görüşleri şu şekildedir;

Öğretmen $:$ : "Eksikliklerimiz ya da bir ihtiyacımız olduğu zaman hızlı bir şekilde temin edilmesi çok önemli. Materyal bulmak, etkinlik hazırlamak oldukça güç."

Öğretmen2: "Öğretmen olarak hadi yapalım. Ne yapabiliriz? Bide kaldı ki sadece görme engeli de değil. Diğer ek engelleri olan öğrenciler de oluyor. Çocuğa bir şey yazdırıyorum ben derste, çocuk evde okusun diye. Çocuk yazdı acaba doğru mu yazdı? En azından bunu görmem lazım benim, Braille bilmem lazım.”

\section{Tasarım, Geliştirme ve Uygulama Aşamaları}

İhtiyaç analizi sürecinde öğretmen ve öğrencilerle yapılan görüşmeler ve sınıf içi gözlemler neticesinde tespit edilen ihtiyaçlara cevap verebilecek ve konuyla ilgili kavramların etkili öğrenimini sağlayacak bir öğretim tasarımının oluşturulabilmesi amacıyla GİGDA'dan yararlanılarak her öğrencinin işlevsel görmeleri değerlendirilmiştir (Tablo 4). Böylece uygulamada kullanılacak materyal ve etkinliklerin öğrencilerin görme düzeyleri ve ihtiyaçlarına uygun olması için taşıması gereken nitelikler belirlenmiş ve tasarım bu verilere göre şekillendirilmiştir.

Tablo 4. Uygulama Grubu Öğrencilerinin GİGDA’ya Bağlı Özellikleri

\begin{tabular}{|c|c|c|c|c|c|}
\hline Öğrenci & Cinsiyet & Yaş & Görme düzeyi & Görme durumu & Okuma becerisi \\
\hline Ö$_{\mathrm{U} .1}$ & Erkek & 11 & Az gören & $\begin{array}{l}3 \text { metre uzakl1ktan 10x10 } \\
\text { ebatlarındaki görsellere tepki verir. }\end{array}$ & $\begin{array}{l}15 \mathrm{~cm} \text { uzaklıktan, } 2 \text { satır aralığında, Century Gothic } \\
\text { karakteri ile yazılan yazılar }\end{array}$ \\
\hline ÖU. $2_{1}$ & Erkek & 12 & Az gören & $\begin{array}{l}1 \text { metre uzaklıktan } 10 \times 10 \text { ebadındaki } \\
\text { görsellere tepki verir. }\end{array}$ & $\begin{array}{l}15 \mathrm{~cm} \text { uzaklıktan, } 2 \text { satır aralığında, Century Gothic } \\
\text { karakteri ile yazılan yazılar }\end{array}$ \\
\hline ÖU. $3_{3}$ & Erkek & 12 & Az gören & $\begin{array}{l}2 \text { metre uzaklıktan } 10 \times 10 \text { ebadındaki } \\
\text { görsellere tepki verir. }\end{array}$ & $\begin{array}{l}10 \mathrm{~cm} \text { uzaklıktan, } 2 \text { satır aralığında, Century Gothic } \\
\text { karakteri ile yazılan yazılar }\end{array}$ \\
\hline$\ddot{O ̈}_{\mathrm{U} .4}$ & Kiz & 12 & Az gören & $\begin{array}{l}3 \text { metre uzaklıktan } 10 \times 10 \text { ebadındaki } \\
\text { görsellere tepki verir. }\end{array}$ & $\begin{array}{l}15 \mathrm{~cm} \text { uzaklıktan, } 2 \text { satır aralığında, Century Gothic } \\
\text { karakteri ile yazılan yazılar }\end{array}$ \\
\hline$\ddot{O}_{\mathrm{U} .5}$ & Erkek & 13 & Kör & Dokunsal materyalleri algilar. & Braille \\
\hline $\mathrm{O}_{\mathrm{U} .6}$ & $\mathrm{~K} 1 \mathrm{z}$ & 12 & Kör & Dokunsal materyalleri algilar. & Braille \\
\hline$\ddot{O}_{\mathrm{U} .7}$ & Erkek & 12 & Az gören & $\begin{array}{l}2 \text { metre uzaklıktan } 10 \times 10 \text { ebadındaki } \\
\text { görsellere tepki verir. }\end{array}$ & $\begin{array}{l}15 \mathrm{~cm} \text { uzaklıktan, } 2 \text { satır aralığında, Century Gothic } \\
\text { karakteri ile yazılan yazılar }\end{array}$ \\
\hline$\ddot{O}_{\mathrm{U} .8}$ & Erkek & 12 & Kör & Dokunsal materyalleri algılar. & Braille \\
\hline ÖU.9 $_{1}$ & $\mathrm{~K} 1 \mathrm{Z}$ & 16 & Kör & Dokunsal materyalleri algilar. & Braille \\
\hline
\end{tabular}

Öğrencilerin işlevsel görmelerinin değerlendirilmesinin ardından ilgili konuya ait kazanımlar Bloom'un yeniden gözden geçirilmiş taksonomisine göre sınıflandırılarak (Anderson \& Krathwohl, 2014), kazanımlar arasındaki ilişkiler somut bir biçimde görülmüş, konunun öğretimindeki genel yaklaşım hakkında fikir sahibi olunmuş ve bu sayede kazanımların öğretim programında öngörüldüğü şekilde öğrencilere kazandırılması amaçlanmıştır. Daha sonra kazanımlara uygun içerik öğretim ilkelerine göre düzenlenmiş, hangi yöntem ve tekniklerin kullanılacağına karar verilmiştir. Öğrenci ders ve çalışma kitapları, öğretmen kılavuz kitapları ve çeşitli ders notlarından faydalanılarak konuya yönelik etkinlik ve materyaller seçilmiş/tasarlanmış/uyarlanmış ve bilgi yaprakları hazırlanmıştır. Bu süreçte hem kör hem de az gören öğrencilerin bireysel ihtiyaçları dikkate alınmıştır. Son olarak öğretmen kılavuzu hazırlanmış, öğretmenin ders saatleri ayarlanmış ve ders materyallerinin dersten önce temini ve hazırlı̆̆ı gibi konular üzerinde düşünülmüştür. Öğretmene uygulama süreci ve öğretmen kılavuzunun kullanımı hakkında bilgilendirmeler de yapılarak tasarımın uygulama sürecine geçilmiştir. Uygulama süreci boyunca yine öğretmene her haftanın başında o hafta işlenecek konuyla ilgili bilgi yaprakları, etkinlikler ve materyallerin tanıtımı yapılarak bizzat kullandırılmış ve öğretim sırasında nelere dikkat etmesi gerektiği üzerinde durulmuştur.

Uygulama aşamasında gerçekleştirilen her bir etkinliğin başlangıcında ön bilgileri harekete geçirmek, etkinliğe ilişkin farkındalık kazandırmak, derse güdülemek ve motivasyonu arttırmak amacıyla öğrencilere konuya ilişkin hazırlık soruları yöneltilmiştir. Etkinlik esnasında da öğrenciler bilgi yaprakları ve materyalleri incelerken tüm süreç boyunca başta kör öğrenciler olmak üzere tüm öğrencilere ayrıntılı betimleme ve açıklamalarda bulunulmuştur. Etkinliklerin sonunda ise öğrencilere değerlendirme soruları yöneltilerek konu kısaca özetlenmiş ve etkinlik sonlandırılmıştır.

"Kemiğin Yapısını İnceleyelim" adlı ilk etkinlik; kemikte bulunan yapıları ve görevlerini kavramak, kemiğin özellikleri hakkında bilgi sahibi olmak amacıyla tasarlanmıştır. Öncelikle öğrencilere çiğ tavuk bacağından alınan kemikler verilerek, bunları eğip bükmeye çalışmaları söylenmiş, sonrasında bu kemiklerden biri su, diğeri de sirke dolu bir kavanoza koyulup bir hafta bekletilmiştir (Şekil 1). 


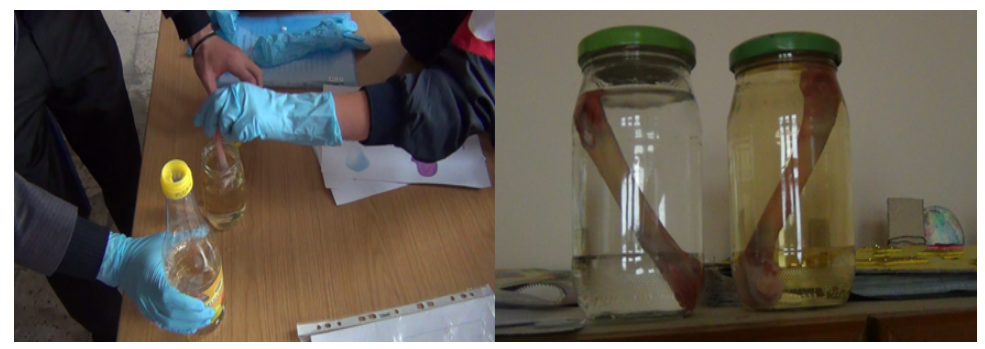

Şekil 1. Kemiklerin su ve sirke içinde bekletilmesi

İlk aşamadan sonra öğrencilere, kemiğin yapı ve kısımlarının renkli ve kabartma şeklinde yer aldığı bilgi yaprakları verilerek incelemeleri sağlanmıștır. Ardından öğrencilere boyuna ikiye kesilmiş kuzu kol kemikleri ve büyüteçler dağıtılarak kemikler üzerinde bulunan yapıları incelemeleri için firsat verilmiştir. $\mathrm{Bu}$ esnada kör öğrencilere gözlemlerinde birebir yardımcı olunmuş, ayrıntılı betimlemeler yapılmıştır. Son olarak kemikte bulunan yapılar görevleriyle birlikte ayrıntılı olarak açıklanmıştır (Şekil 2). Bir hafta sonraki derste su ve sirke dolu kavanozlarda bekletilen tavuk kemikleri incelenmiş ve su içinde bulunan kemiğin hala sertliğini korurken, sirke içinde bekletilen kemiğin neden yumuşamış olduğu sınıfça tartışılmıştır.

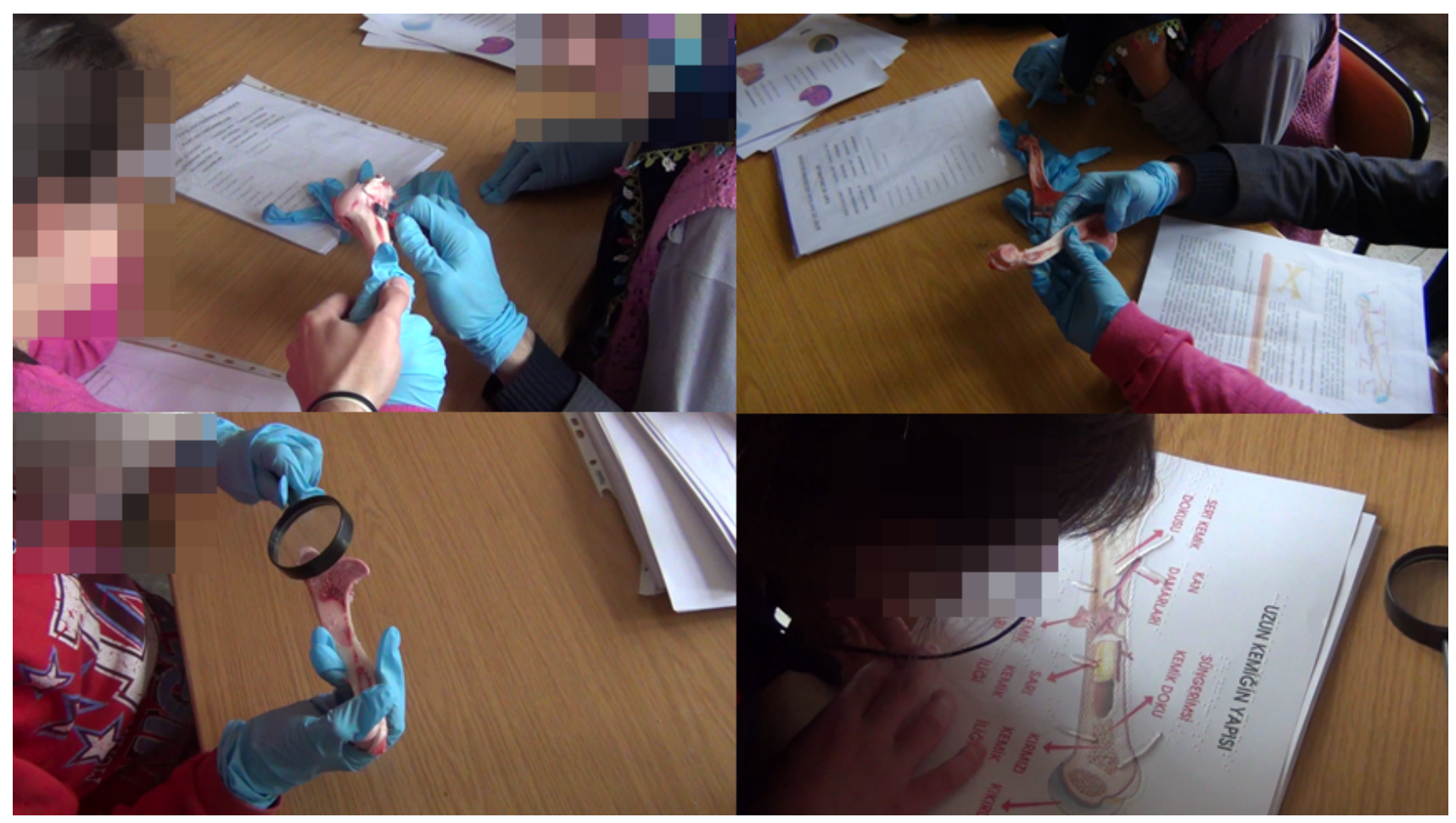

Şekil 2. Etkinlik 1'in uygulanmas1

Kemiklerin farklı şekillerde olduğunu kavramak ve vücutta bulunan kemikleri şekillerine göre gruplandırmak amacıyla tasarlanan "İskeletimizdeki Kemik Çeşitleri”" adlı ikinci etkinlikte, insan iskeleti modeli üzerinde öğrencilere kemiklerin şekillerine göre kaç çeşit olabileceği kavratılmış ve ardından ellerine verilen kemik modellerini şekillerine göre gruplandırmaları istenmiştir. Son olarak öğrencilere araştırmacılar tarafından tasarlanan iskelet sistemi modeli verilerek, vücutta bulunan belli başlı kemik isimleri kavratılmıştır (Şekil 3). 


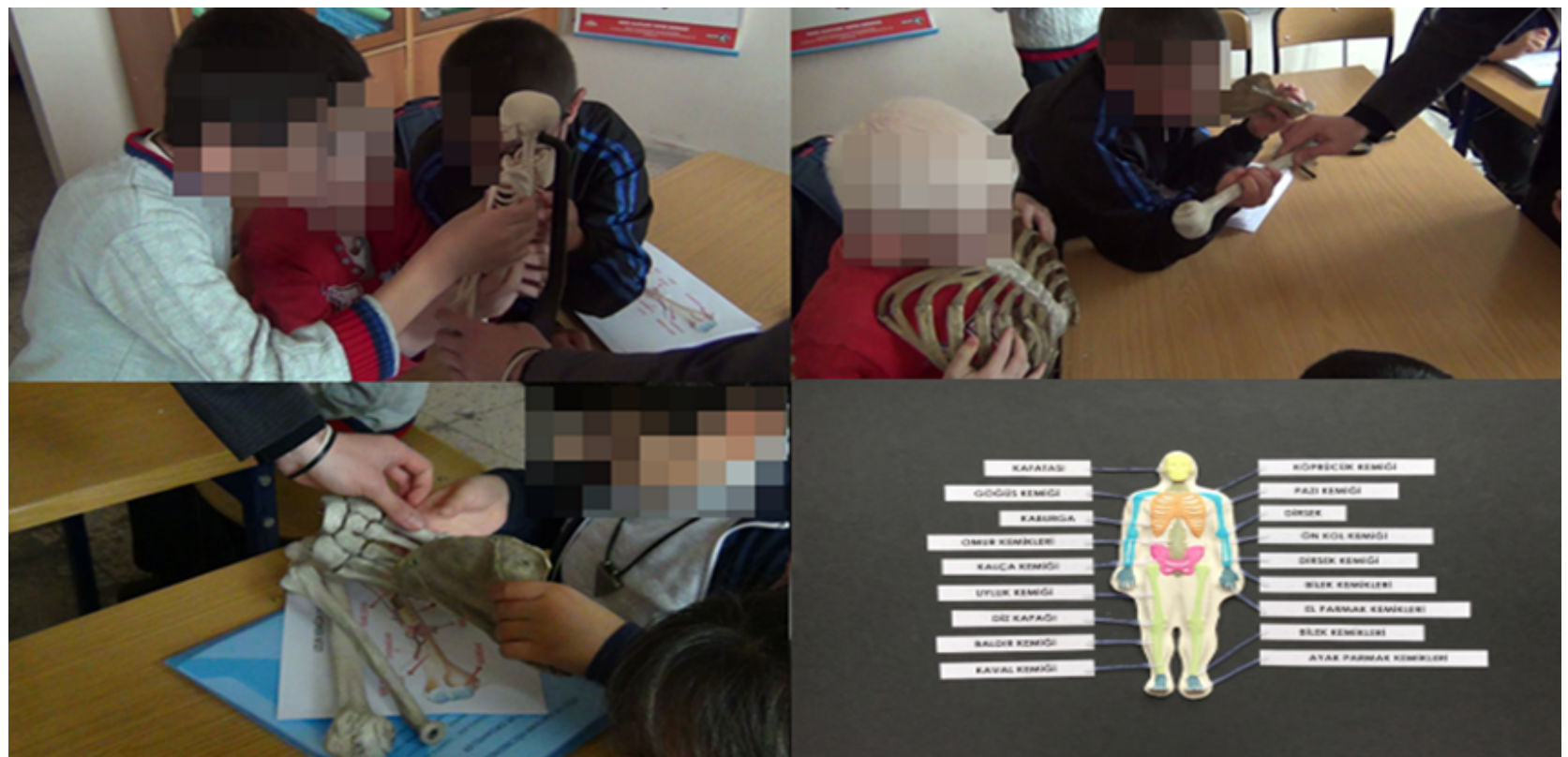

Şekil 3. Etkinlik 2'nin uygulanmas1

İskelet sistemi modelinin tasarım sürecinde iskelette bulunan kemikleri ayrıntılı olarak gösterebilen kalıptan yararlanılmıştır. Bu kalıbın içine dökülen alçı kuruduktan sonra çıkartılıp üzeri siyah fon kartonuyla kaplı ahşap bir düzleme yapıştırılmıştır. Dokunsal özellikte olan bu modelin az gören öğrenciler için de kullanılabilir olması amacıyla model üzerindeki kabartma kemik bölgeleri alçı boyası kullanılarak çeşitli renklerde boyanmış ve model üzerinde şekilzemin zitlığ oluşturularak kemikler görsel olarak daha belirgin hale getirilmiştir. Ardından model üzerinde yer alan kemiklerin isimleri etiketler üzerine hem büyük punto hem de Braille alfabeyle yazılarak ahşap düzleme yapıştırılmış ve bu etiketler sıcak silikon tabancası kullanılarak model üzerinde ilgili olduğu kemiklerle eşleştirilmiştir.

"Eklemlere Gerek Var Mıdır?" adlı üçüncü etkinlik, eklemlerin hareket etmemize yardımcı olduğunu kavramak amacıyla tasarlanmıştır. Etkinlikte öğrencilerin yazı yazmak için kullandıkları ellerinin parmaklarına karton rulolar geçirilerek sabitlenmiş ve öğrencilerden bağlı olan ellerini kullanarak yazı yazma, herhangi bir eşya tutma, ayakkabılarını bağlama, saçlarını tarama, kitaplarını taşıma vb. görevleri yapmaları istenmiştir (Şekil 4). Ardından öğrenciler, değerlendirme soruları eşliğinde hareket etmek ya da günlük işleri yapmak için eklem adı verilen yapılara ihtiyaç duyulduğu konusunda düşündürülmüş ve etkinlik sona erdirilmiştir.

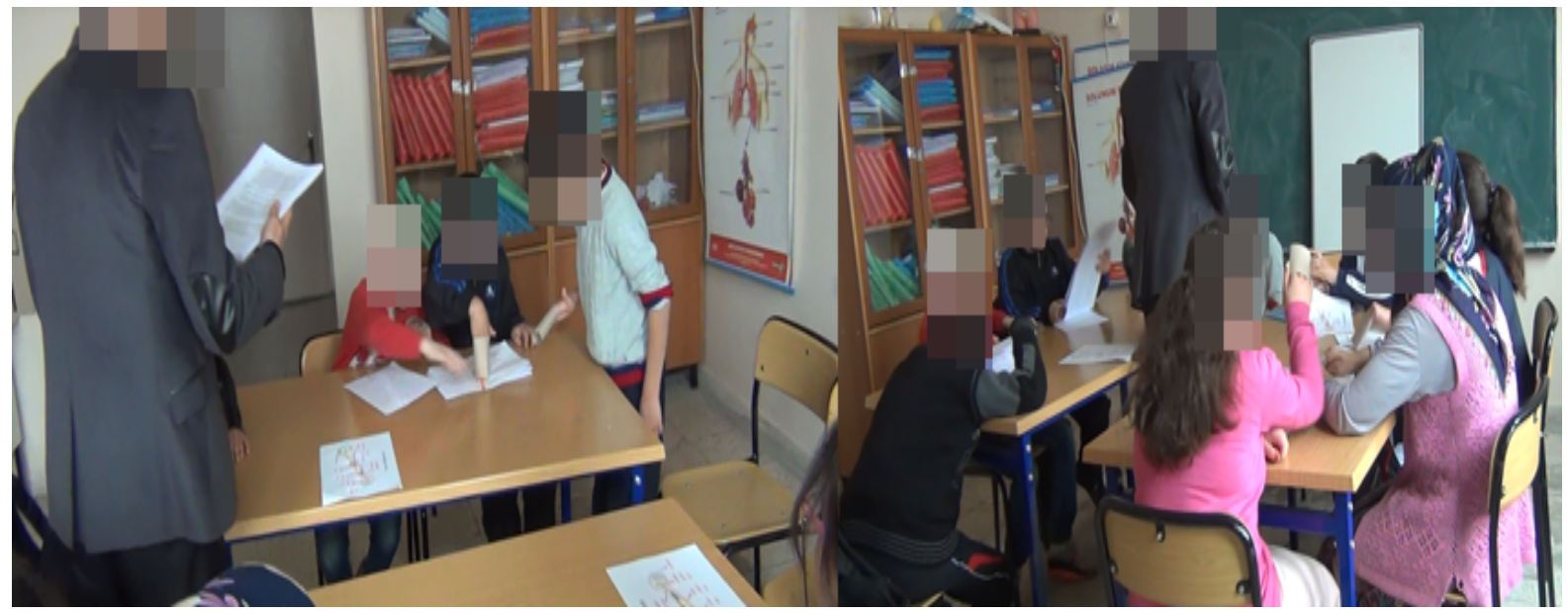

Şekil 4. Etkinlik 3'ün uygulanması

Eklem çeşitleri hakkında bilgi sahibi olmak ve eklemin yapısını oynar eklem üzerinden kavramak amacıyla tasarlanan "Eklemleri Tanıyalım" adlı dördüncü etkinlikte öğrencilere her bir eklem çeşidine ait bilgi yaprakları ve 3D modeller sırasıyla dağıtılarak incelemeleri için firsat verilmiştir (Şekil 5). Ayrıca öğrencilere çeşitli hareketler yaptırılarak eklem çeşitlerinin özelliklerini uygulamalı olarak kavramaları sağlanmıştır. 


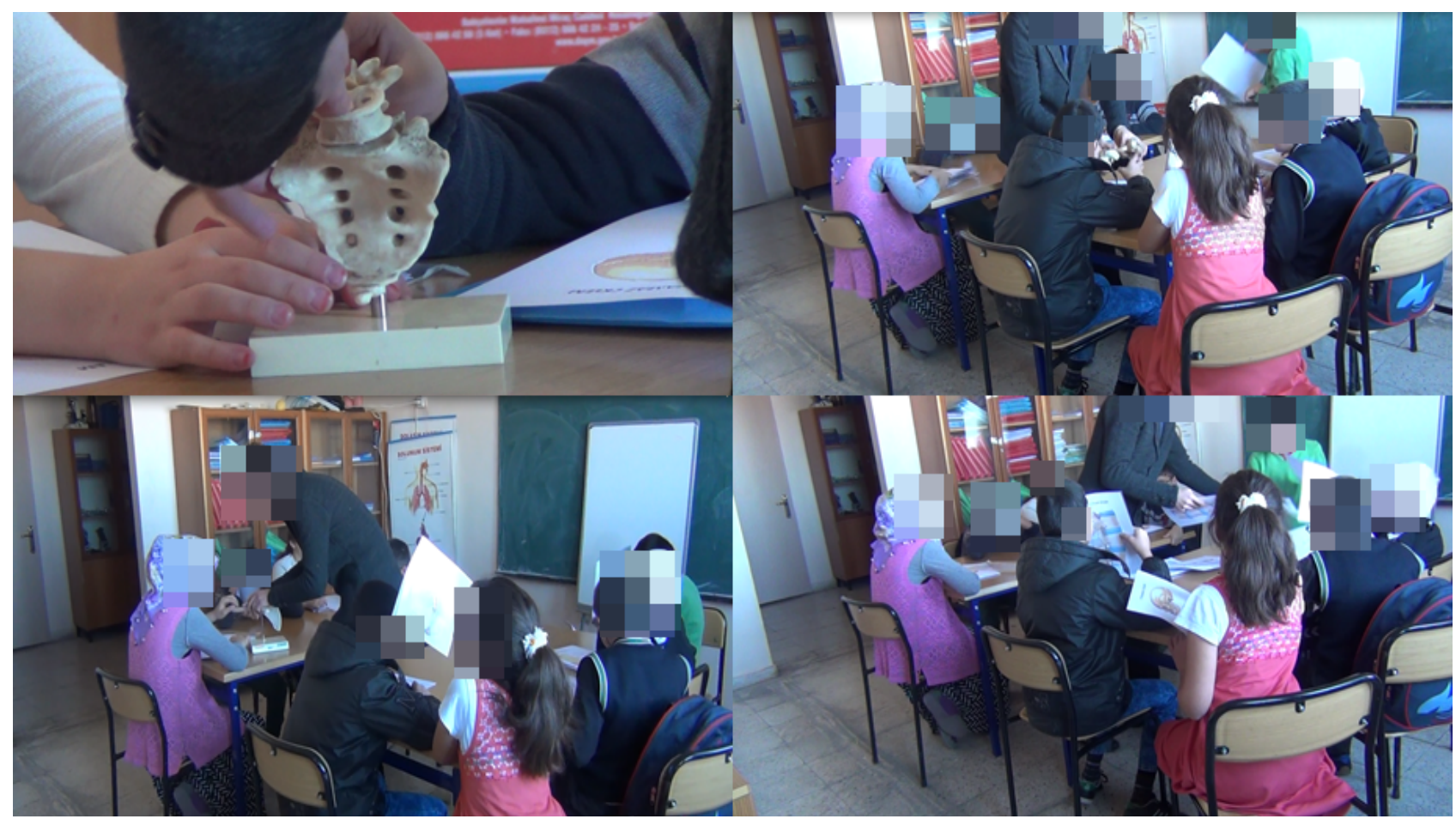

Şekil 5. Etkinlik 4'ün uygulanmas

"Vücudumuzdaki Kaslar" adlı beşinci etkinliğin amacı, vücutta bulunan kas çeşitlerini ve özelliklerini kavramaktır. $\mathrm{Bu}$ amaçla her bir öğrenciye kas çeşitleri hakkında bilgi ve kabartma çizim içeren bilgi yaprakları dağıtılmış ve incelemeleri için firsat verilmiştir. Ardından bir parça haşlanmış et havanda dövülerek kasların lifli bir yapıda olduğu öğrencilere kavratılmaya çalışılmıştır (Şekil 6).

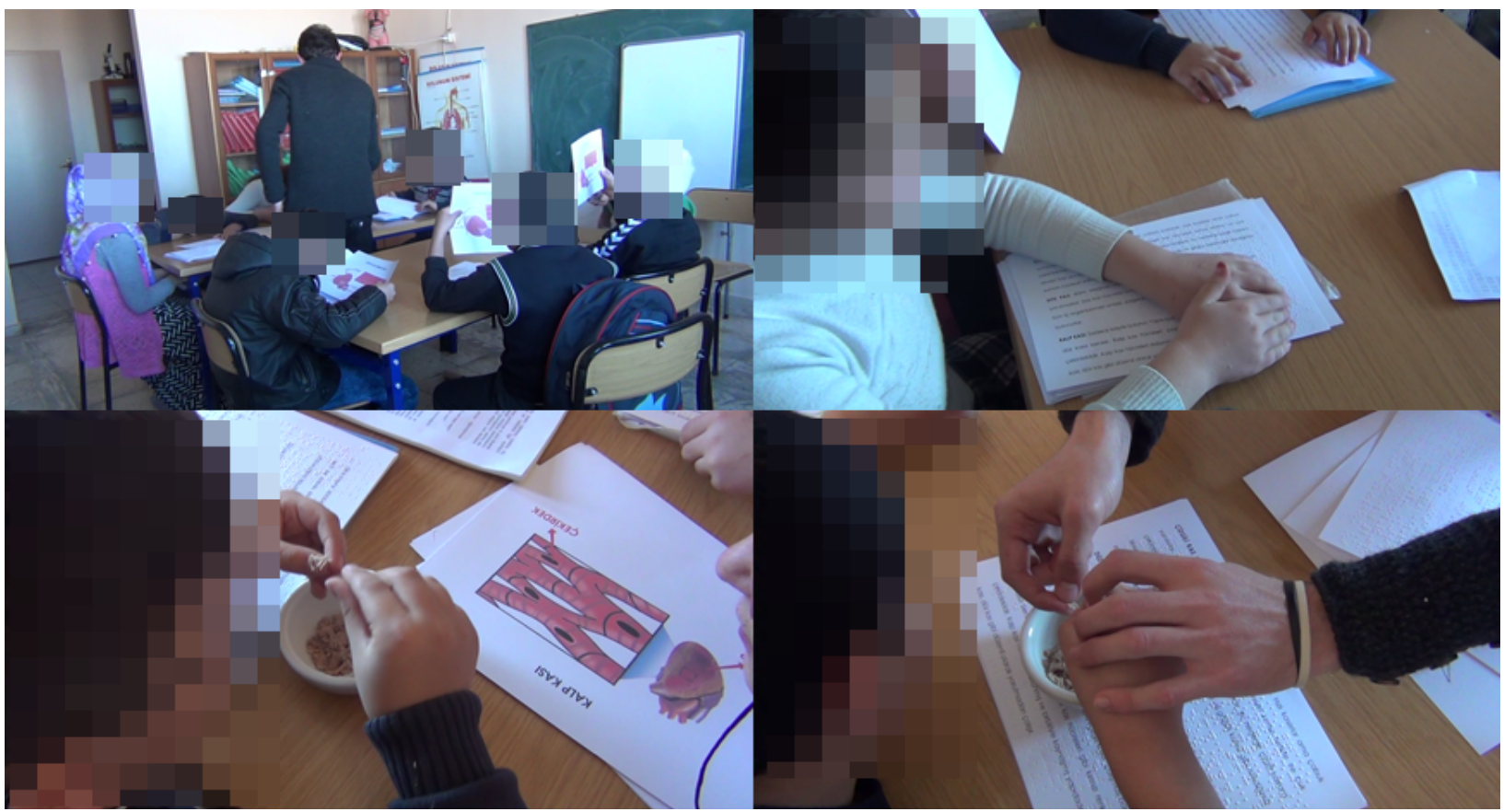

Şekil 6. Etkinlik 5'in uygulanmas1

Çizgili kasların çalışma prensibini kavramak amacıyla tasarlanmış "Kasları Çalıştıralım” adlı altıncı etkinlikte öğrencilerin, kasılan ya da gevşeyen bir kasta ne gibi değişimlerin olacağını zıt çalışan kas modeli üzerinde kavramaları hedeflenmiştir. Bunun için öncelikle iki masada iki ayrı gruba ayrılan öğrencilere önlerinde bulunan malzemeleri tanımaları için firsat verilmiştir. Bu esnada öğretmen sırasıyla tüm malzemeleri öğrencilere betimleyerek etkinlik esnasında bu malzemeleri nasıl kullanacaklarını ayrıntılı olarak açıklamış, modelleri oluştururken her adımda öğrencilere birebir yardımcı olmuştur (Şekil 7). 


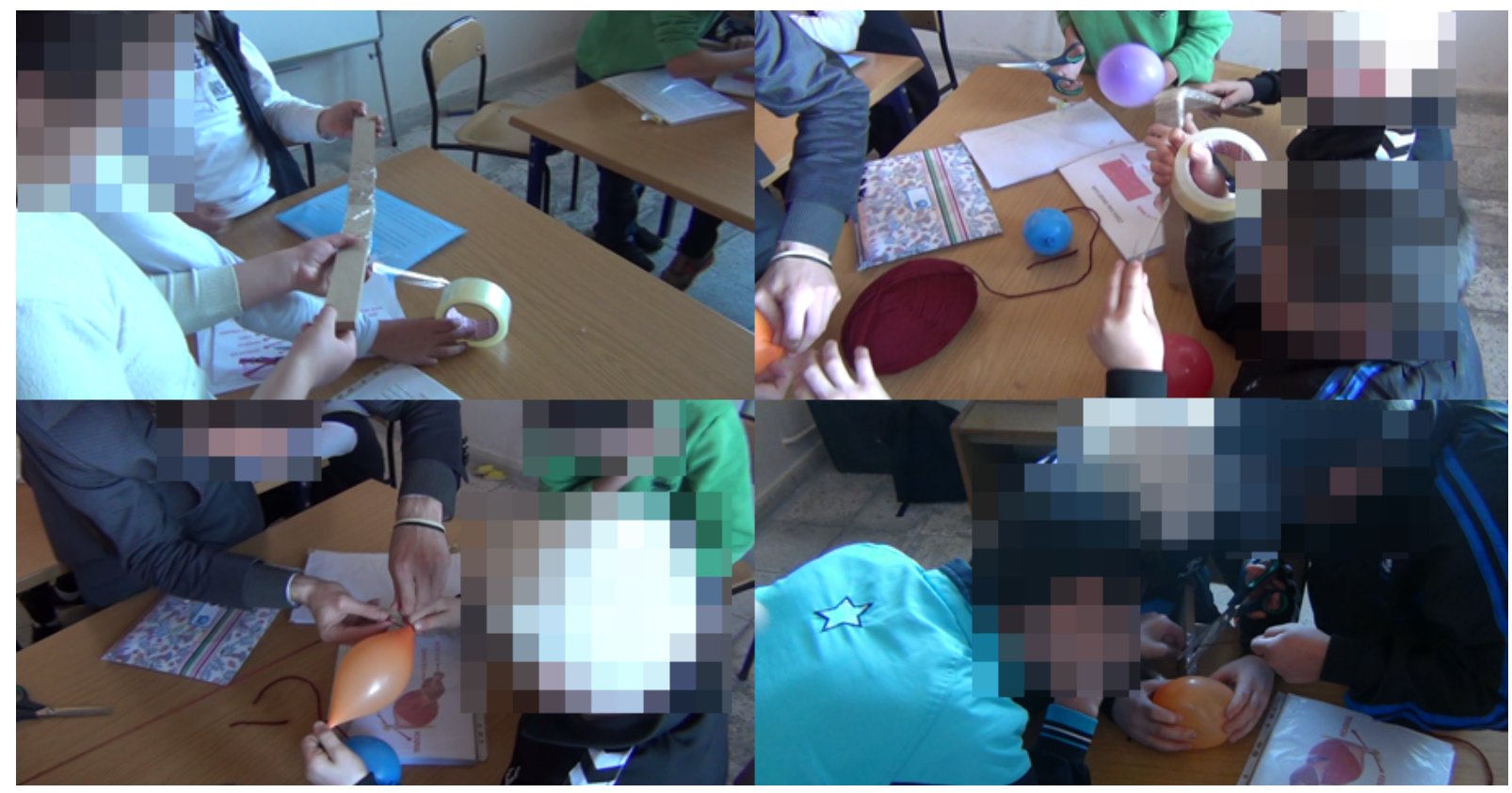

Şekil 7. Öğrencilerin zıt çalışan kaslar modelini oluşturmaları

Oluşturdukları zıt çalışan kas modelleri üzerinde öğrencilere inceleme yapma imkânı verilmiş, bu esnada gerekli betimleme ve açıklamalar yapılarak kasların çalışma prensibi kavratılmıştır (Şekil 8).

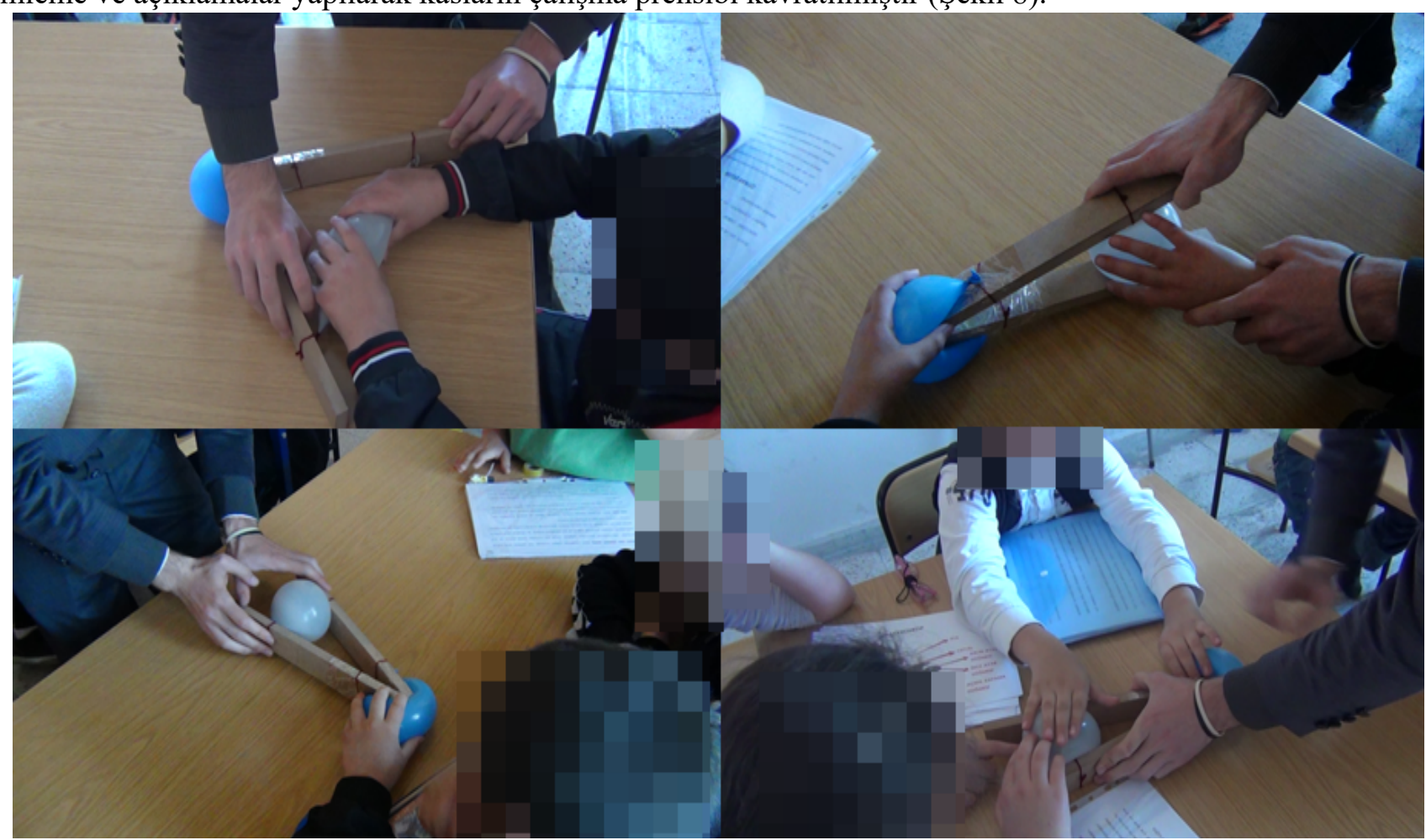

Şekil 8. Öğrencilerin zıt çalışan kaslar modelini incelemeleri

"Hareketlerimiz Sağlığımızı Nasıl Etkiler?" adlı yedinci etkinliğin amacı; destek ve hareket sistemini olumlu/olumsuz yönde etkileyen hareketler konusunda bilgi sahibi olmaktır. Bu amaçla öğrencilere, çeşitli resimler içeren bilgi yaprakları dağıtılarak üzerlerinde bulunan hareketlerden hangilerinin olumlu, hangilerinin olumsuz olabileceği konusunda fikir yürütmeleri istenmiştir. Kör öğrencilere ise bu hareketler uygulamalı olarak gösterilmiş ve yapılan hareketleri olumlu ya da olumsuz olarak gruplandırmaları istenmiştir (Şekil 9). Ardından yapılan hareketlerin niçin olumlu/olumsuz olduğu değerlendirme soruları eşliğinde tartışılmış, bu hareketler dışında günlük yaşamda yapılan başka hareketlerin de sağlığa uygunluğu irdelenmiştir. Son olarak destek ve hareket sisteminin sağlığını korumak için uygun hareketler yapmanın dışında nelere dikkat edilmesi gerektiği, bu sistemin hastalıları ve tedavi yöntemleri konularında ayrıntılı açıklamalar yapılmıştır. 


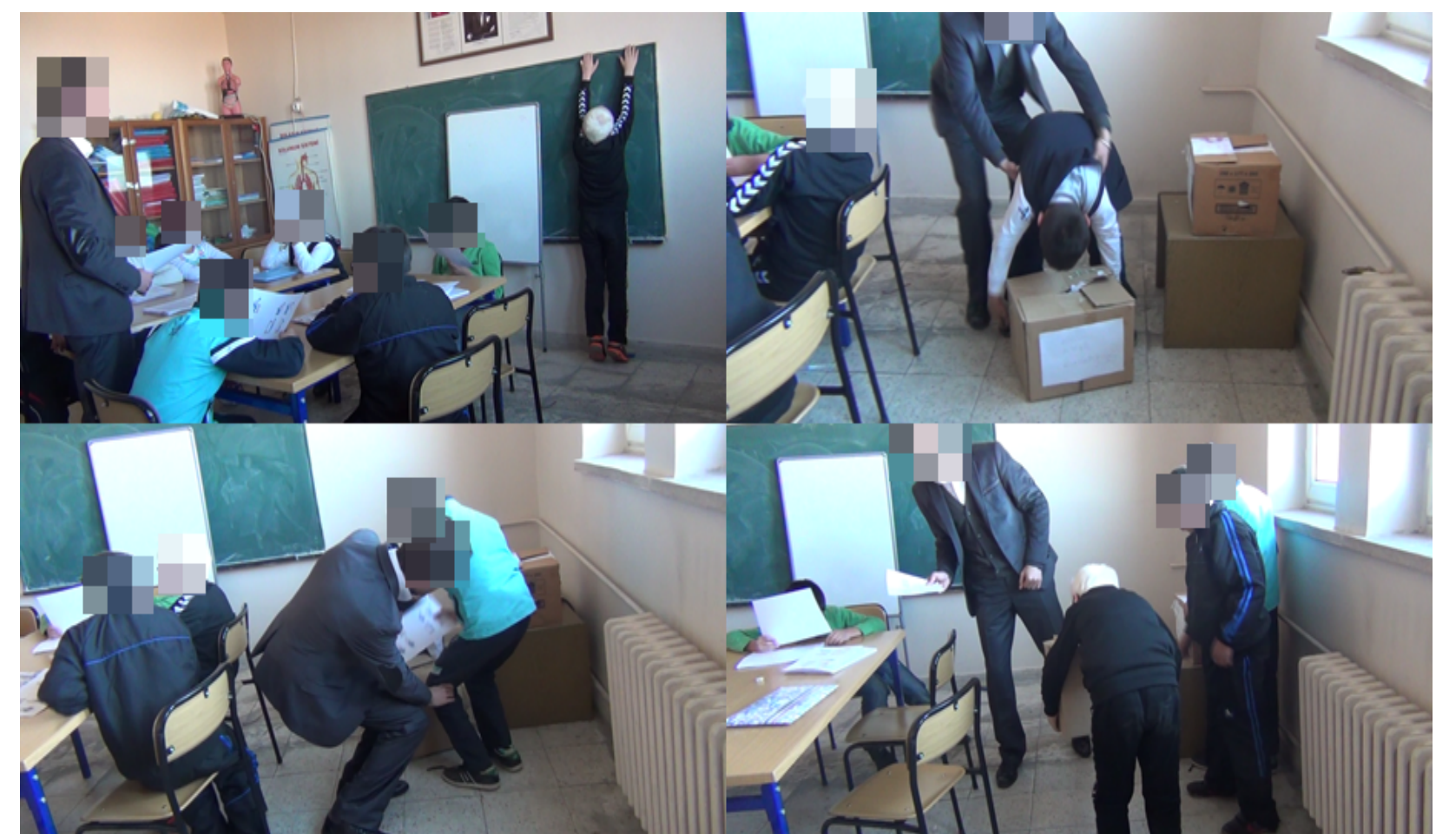

Şekil 9. Etkinlik 7'nin uygulanmas1

İskelet ve kas sağlığını korunmak için yapılması gerekenlerin pekiştirilmesi amacıyla tasarlanmış "Oynuyorum, Tartışıyorum" adlı sekizinci etkinlikte öğrenciler iki gruba ayrıldıktan sonra Ahmet ile Mehmet'in alışkanlıkları hakkında öğretmen kılavuzundaki metin öğretmen tarafindan sınıfa okunmuştur. Sonrasında öğrencilerden, önceki etkinliklerde öğrendiklerinden yola çıkarak Ahmet ile Mehmet' in alışkanlıklarını doğru/yanlış olarak sınıflandırmaları, bu alışkanlıklarının yaşamlarını nasıl etkileyebileceği üzerinde düşünmeleri istenmiştir. Ardından her grup kendi içinden bir kişiyi grup sözcüsü olarak belirlemiş ve bu grup sözcülerinden biri Ahmet'i diğeri ise Mehmet'i canlandırmıştır (Şekil 10).

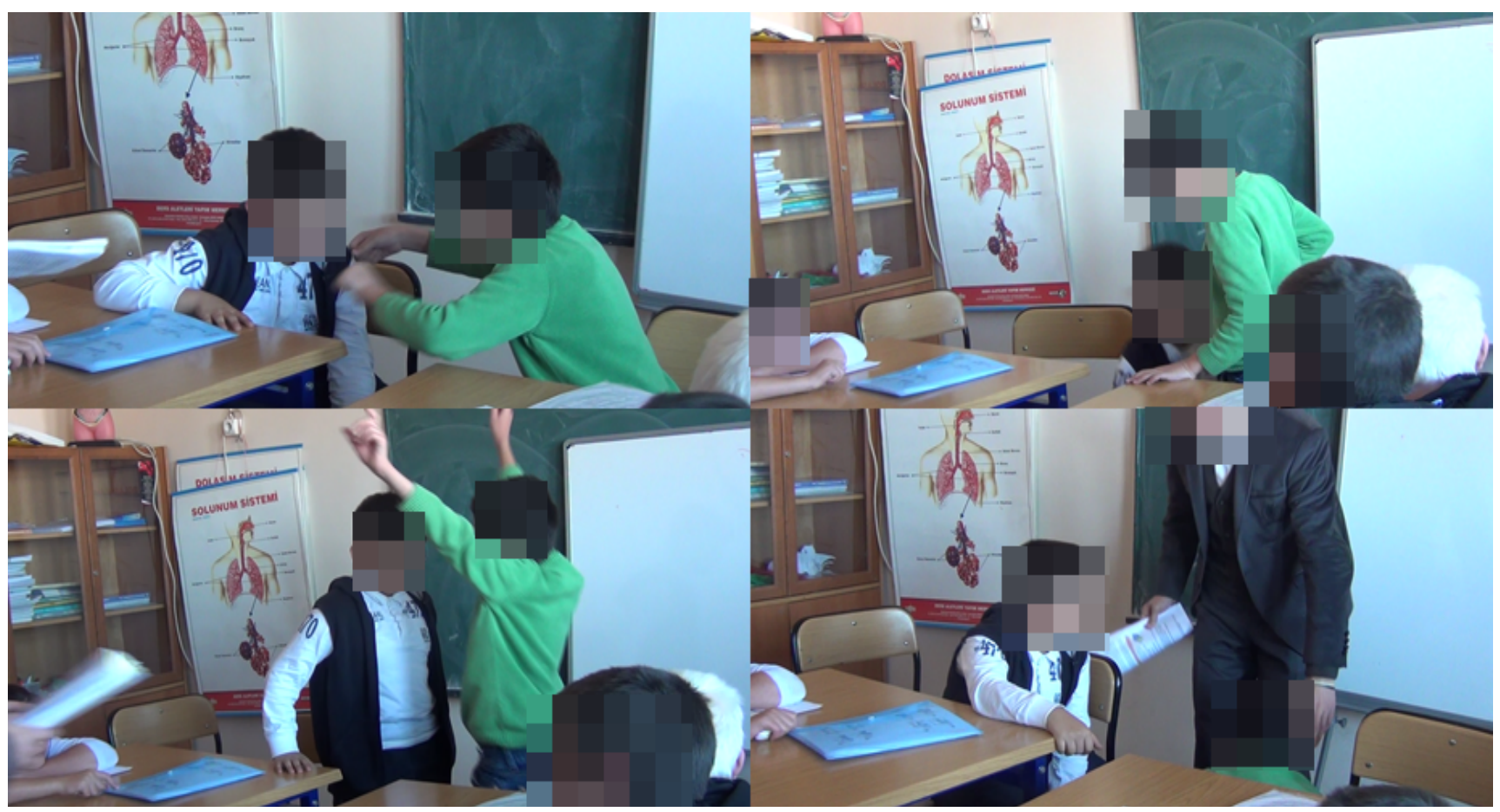

Şekil 10. Etkinlik 8'in uygulanması

"Engelleri Aşmak" adlı dokuzuncu etkinlik, engelli bireylerin yaşadıkları zorlukların ve bu konuda yapılması gerekenlerin neler olduğunun farkına varılması amacıyla tasarlanmıştır. Üzerinde engelli bireylerle ilgili üç farklı soru (yaşadıkları çevrenin tekerlekli sandalye kullanan bir kişi için uygun olup olmadığı, bu kişiler için ne gibi düzenlemeler 
yapılabileceği, görme engelli biri olarak çevreden ne tür beklentileri olduğu) bulunan bilgi yaprakları öğrencilere dağıtılarak bu soruları cevaplandırmaları için zaman verilmiştir. Sorulara verilen cevaplar bir tartışma ortamı yaratılarak sinıfla paylaşılmıştır (Şekil 11).

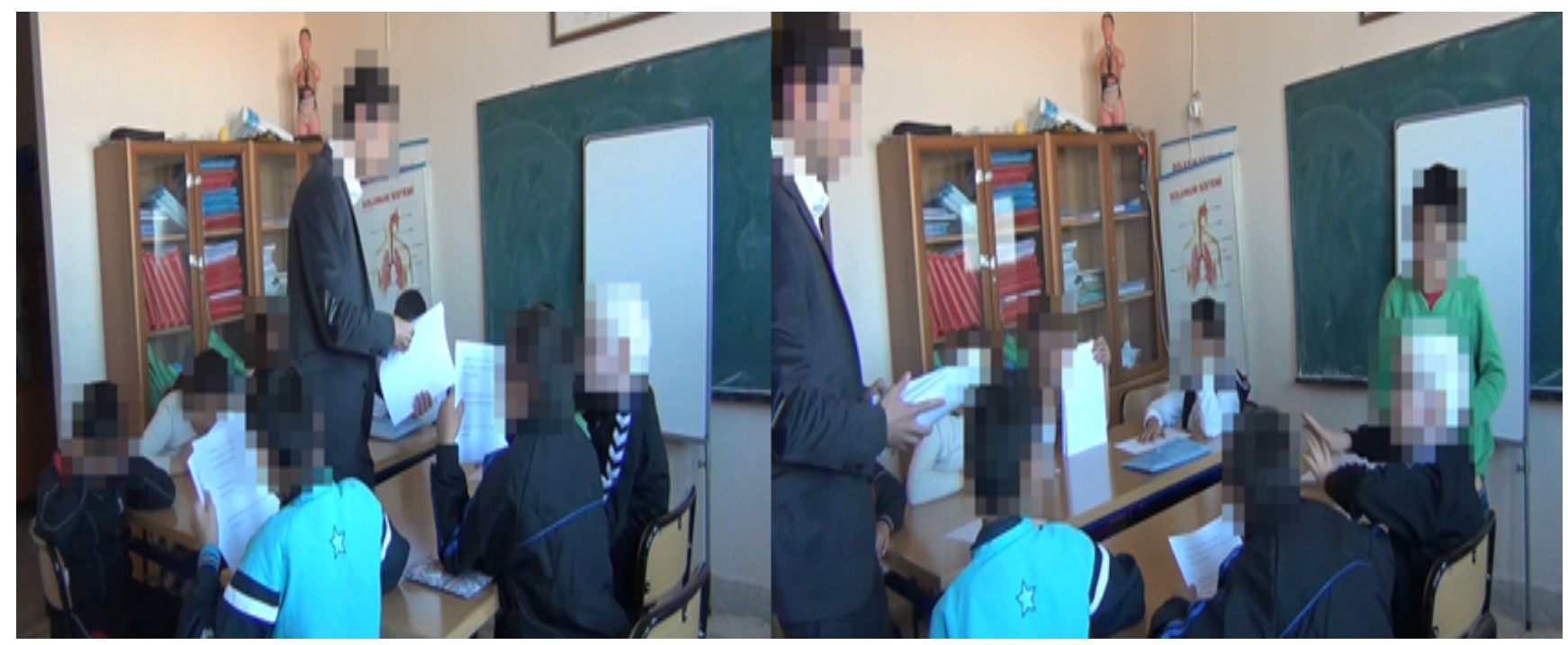

Şekil 11. Etkinlik 9'un uygulanmas1

\section{Değerlendirme Așaması}

"Destek ve Hareket Sistemi” konusunda uygulanan dokuz etkinliğin işe yararlılığını tespit etmek, tasarımın öğretime ve öğrenciye uygunluğunu belirlemek, işlevselliğini ve kullanışlılığını ortaya çıkarmak amacıyla FEGF'den yararlanılarak değerlendirme yapılmıştır. Bu değerlendirmeye ilişkin veriler Tablo 5'de sunulmuştur.

Tablo 5. Destek ve hareket sistemi konusuna ait etkinliklerinin değerlendirilmesi

Değerlendirme Boyutları

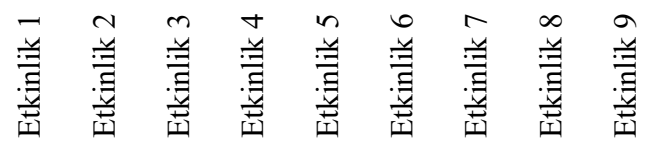

\section{1. Öğretime Uygunluk}

1.1. Etkinlik başlangıcında sorulan sorular ön bilgileri test ediyor mu?

1.2. Etkinlik öncesindeki hazırlık soruları etkinliğe ilişkin farkındalık oluşturabiliyor mu?

1.3. Etkinlik ve kullanılacak malzemelerin tanıtımı için verilen zaman yeterli mi?

1.4. Etkinlik planlanan konunun amaciyla uyumlu mu? 2. Ögrenciye Uygunluk

2.1. Etkinlik farklı duyuların kullanımına firsat tanıyor mu?

2.2. Etkinlik günlük hayattaki olaylardan uyarlanarak kurgulanmış mı?

2.3. Etkinlik önceki ögrenmelerle ilişki kurmaya yardımcı olabiliyor mu?

2.4. Etkinlik öğrencinin fiziksel ve zihinsel olarak katılımını sağlıyor mu?

2.5. Etkinlik öğrencilerin ilgisini çekebiliyor mu?

2.6. Etkinlik hedef grubun bilişsel özelliklerine uygun mu? 3. İşlevsellik

3.1. Etkinlik ilgili hedeflere ulaşmayı sağlayacak nitelikte mi?

3.2. Etkinlik kapsamında kullanılan malzemeler tekrar kullanıma uygun mu?

3.3. Etkinlik öğrencinin bağımsız çalışmasına firsat tanıyabilecek nitelikte mi?

3.4. Etkinlik bireysel farklılıklara göre uyarlanabilme özelliğine sahip mi? 4. Kullanışlilık

4.1. Etkinlik için planlanan zaman yeterli mi?

4.2. Etkinlikte kullanılan malzemeler maliyet açısından ekonomik mi?

4.3. Etkinlikte kullanılan malzemeler kolay ulaşılabilir nitelikte mi?

4.4. Etkinlikte kullanılan malzemeler kolay kullanılabilir nitelikte mi?

4.5. Etkinlik öğrencinin güvenliğini ön planda tutuyor mu?

\begin{tabular}{ccccccccc}
+ & + & + & + & + & + & + & + & + \\
+ & + & + & + & + & + & + & + & + \\
+ & + & + & + & + & + & + & + & + \\
+ & + & + & + & + & + & + & + & + \\
\hline
\end{tabular}

*Uygun $(+)$, kısmen uygun $(\bullet)$, uygun değil $(-)$, değerlendirilemez (x) 
Tablo 5 incelendiğinde kriter 2.2 açısından etkinlik 1, 2, 4, 5 ve 6 değerlendirilemezken, etkinlik 6 kriter 2.4'e göre kısmen yeterli görülmüştür. Bunun nedeni olarak kör öğrenciler, zıt çalışan kaslar modelini oluşturmada beklenen başarıyı gösteremezken, az gören öğrencilerin bu konuda oldukça istekli davranması ve kör öğrencilere göre daha iyi bir performans göstermeleridir. Ayrıca az gören öğrencilerin de balonları şişirdikten sonra ağızlarını bağlama, bu balonları çıtalara sabitleme vb. görevlerde zorlanmaları ve fazlaca öğretmen desteğine ihtiyaç duymaları nedeniyle altıncı etkinlik kriter 3.3 ve 4.1 bakımından uygun bulunmamıştır.

Öğrenciler etkinlik 1'de gerçek kemik modelleri ve renkli/kabartma kemik çizimleri bulunan bilgi yapraklarını inceleyerek kemikte bulunan yapıları ayrıntılı olarak incelemişler, fakat bu yapıların görevleri hakkında kendilerine herhangi bir bilgi yaprağı verilmediği için bu yapıların görevlerini sadece öğretmeninden dinleyerek öğrenmeye çalışmışlardır. Uygulama sonrası yapılan görüşmelerde öğrencilerin bir kısmı kemikte bulunan yapıları rahatlıkla söyleyebildikleri halde bu yapıların görevlerini ifade ederken zorlanmışlardır. Bu nedenle söz konusu etkinlik kriter 3.1 ve 3.3 açısından kısmen uygundur (Tablo 5). Sekizinci etkinlikte, öğretmenin okuduğu metin öğrenciler tarafından canlandırıldığı için herhangi bir materyal kullanılmamış, bu nedenle söz konusu etkinlik kriter 3.2, 4.2, 4.3, 4.4'e göre değerlendirilememiştir (Tablo 5).

Öğretim programında yer alan "Destek ve Hareket Sistemi” konusuna ait kazanımlar ve konu içeriği dikkate alınarak hazırlanan sorular hem ihtiyaç analizi hem de uygulama grubu öğrencilerine sorulmuş ve ilgili kavramların öğrenciler tarafından ne düzeyde öğrenildiği ortaya çıkarılmıştır. Grupları oluşturan öğrenciler; görme düzeyleri, bireysel ihtiyaçları ve hazırbulunuşlukları bakımından birbiriyle benzer olmasından dolayı, verdikleri cevapların karşıllaştırılması uygulanan tasarımın işe yararlığını görmek açısından bir fikir verecektir. Tablo 6' da ihtiyaç analizi ve uygulama grubu öğrencilerinin soruları cevaplama durumları karşılaştırılmıştır.

Tablo 6. Destek ve hareket sistemi konusuna ait soruların cevaplanma durumlarının karşılaştırılması

\begin{tabular}{|c|c|c|c|c|c|c|c|c|c|c|c|c|c|c|c|c|c|}
\hline \multirow{2}{*}{$\begin{array}{l}\frac{\bar{\pi}}{\vec{\Xi}} \\
\text { है }\end{array}$} & \multicolumn{6}{|c|}{ İhtiyaç Analizi Grubu } & \multirow{2}{*}{ 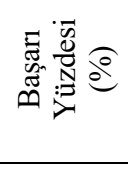 } & \multicolumn{9}{|c|}{ Uygulama Grubu } & \multirow{2}{*}{ 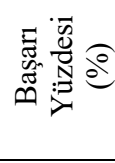 } \\
\hline & $\ddot{O}_{1}$ & $\ddot{\mathrm{O}}_{2}$ & $\ddot{\mathrm{O}}_{3}$ & $\ddot{\mathrm{O}}_{4}$ & $\ddot{O}_{5}$ & $\ddot{\mathrm{O}}_{6}$ & & $\ddot{\mathrm{O}}_{1}$ & $\ddot{\mathrm{O}}_{2}$ & $\ddot{\mathrm{O}}_{3}$ & $\ddot{\mathrm{O}}_{4}$ & $\ddot{\mathrm{O}}_{5}$ & $\ddot{\mathrm{O}}_{6}$ & $\ddot{\mathrm{O}}_{7}$ & $\ddot{\mathrm{O}}_{8}$ & $\ddot{O}_{9}$ & \\
\hline 1 & + & - & $\cdot$ & + & - & $\cdot$ & 50 & + & + & + & + & + & $\cdot$ & + & + & + & 94 \\
\hline 2 & + & - & • & + & • & - & 50 & + & $\cdot$ & + & + & + & - & + & + & + & 83 \\
\hline 3 & + & - & • & • & • & • & 50 & + & + & + & + & + & + & + & + & + & 100 \\
\hline 4 & + & - & + & + & • & + & 75 & + & + & + & + & + & + & + & + & + & 100 \\
\hline $4 a$ & + & - & + & + & - & + & 67 & + & + & + & + & + & + & + & + & + & 100 \\
\hline 5 & + & - & - & • & - & - & 25 & + & • & + & + & + & • & + & + & + & 89 \\
\hline $5 \mathrm{a}$ & • & - & - & • & - & - & 17 & • & - & • & + & • & - & + & + & • & 56 \\
\hline 6 & + & - & - & + & • & - & 42 & + & + & + & + & + & • & + & + & + & 94 \\
\hline 7 & + & - & - & + & - & + & 50 & + & + & + & + & + & • & + & + & + & 94 \\
\hline $7 a$ & • & - & - & • & - & • & 25 & + & $\cdot$ & + & + & + & • & + & + & • & 83 \\
\hline 8 & • & - & - & • & - & - & 17 & - & + & + & + & + & - & + & + & - & 67 \\
\hline 9 & + & - & - & + & • & - & 42 & + & + & + & + & + & + & + & + & - & 89 \\
\hline 10 & + & - & - & + & + & • & 58 & + & + & + & + & + & • & + & + & + & 94 \\
\hline $10 \mathrm{a}$ & + & - & - & + & • & - & 42 & + & $\cdot$ & + & + & $\cdot$ & • & + & + & • & 78 \\
\hline 11 & • & - & - & • & + & • & 42 & + & + & + & + & + & + & + & + & + & 100 \\
\hline 12 & - & - & - & + & - & - & 17 & + & - & + & + & + & - & + & + & - & 67 \\
\hline 13 & • & - & - & + & • & - & 33 & • & + & + & + & + & • & + & + & + & 89 \\
\hline 14 & • & - & - & + & • & - & 33 & • & + & • & + & + & • & + & + & • & 78 \\
\hline 15 & • & - & - & + & • & - & 33 & • & + & + & + & • & - & + & + & • & 72 \\
\hline$\%$ & 76 & 0 & 18 & 84 & 34 & 29 & & 84 & 79 & 95 & 100 & 92 & 50 & 100 & 100 & 71 & \\
\hline
\end{tabular}

*Doğru cevap (+, 2 puan), kısmen doğru cevap $(\cdot, 1$ puan), yanlış cevap (-, 0 puan)

Tablo 6'ya göre; ihtiyaç analizi grubu \%40, uygulama grubu ise \%86 oranında sorulara doğru cevap verebilmişlerdir. Soruların cevaplanma oranlarına bakıldığında bütün sorularda artış gözlenmekle birlikte en fazla başarı artış1 5. soruda (\%64), en az başarı artışı ise 4. soruda (\%25) olmuştur. İhtiyaç analizi grubunda tüm soruları doğru cevaplayabilen öğrenci bulunmazken, uygulama grubunda $\mathrm{O}_{4}, \ddot{O}_{7}$ ve $\ddot{O}_{8}$ tüm soruları tam doğru cevaplayabilmiștir. Yine uygulama grubunda hiçbir soruyu doğru cevaplayamayan öğrenci bulunmazken, ihtiyaç analizi grubundaki $\ddot{O}_{2}$ hiçbir soruyu doğru cevaplayamamıştır. Uygulama grubunda doğru cevaplanma oranı en düşük olan sorunun \%56'l1k oranla soru 5a olduğu görülmektedir (Tablo 6). Soru 5 ve 5a'ya verilen cevaplar birlikte irdelendiğinde öğrencilerin neredeyse tamamına yakını kemiğin yapısında neler bulunduğunu (soru 5) söyleyebilmiş fakat bu yapıların görevlerini söylemede 
(soru 5a) zorlanmışlardır. Uygulama sırasında öğrenciler, gerçek kemiği ve renkli/kabartmalı kemik çizimlerinin bulunduğu bilgi yapraklarını incelemiş, kemikte bulunan yapıları rahatlıkla gözlemleyerek kavrayabilmişlerdir. Ancak bu öğrenciler kemikte hangi yapıların görevleri hakkındaki bilgileri sadece öğretmenlerinden dinlemişler, bununla ilgili herhangi bir bilgi yaprăğ almamışlardır. Dolayısıyla ders dışında bu yapıların görevlerini çalışıp tekrar edebilecekleri bir kaynakları bulunmadığından konuyu tam olarak kavrayamadıkları ve soru 5a'ya beklenen düzeyde doğru cevap veremedikleri görülmüştür. Bu durum, uygulama sırasında kullanılan araç-gereç, materyal ve bilgi yapraklarının, kavramsal öğrenme üzerinde ne kadar etkili olduğunu göstermektedir.

İhtiyaç analizi grubu ile uygulama grubu öğrencilerinin "Destek ve Hareket Sistemi" konusuna ait iki kazanıma ulaşma düzeyleri Tablo 7'de karşılaştııılmıştır. Tablo 7 incelendiğinde; ihtiyaç analizi grubu (\%25) ile uygulama grubu (\%67) arasında kazanımlara ulaşılma düzeyleri açısından oldukça belirgin bir fark olduğu görülmektedir. İhtiyaç analizi grubunda birinci kazanıma \%33, ikinci kazanıma \%17 düzeyinde ulaşılmışken; uygulama grubunda ise bu oran sırasıyla \%78 ve \%56 olmuştur. Bu durumda birinci kazanıma ulaşmada artış \%45, ikinci kazanıma ulaşmada artış ise \%39'dur. Kazanımlara ulaşılma düzeyinde \%0-30 arası düşük, \%30-70 arası orta, \%70 ve üzeri ise yüksek başarı olarak kabul edildiğinde, birinci kazanımda yüksek başarı (\%78) sağlanmışken, ikinci kazanımda ise orta düzeyde başarı (\%56) elde edilmiştir (Tablo 7).

Tablo 7'ye göre Öİ.4 her iki kazanıma ulaşmışken, Öİ.2, Öİ.3, Öİ.5 ve Öİ.6 hiçbir kazanıma ulaşamamıştır. Uygulama grubunda ise ÖU.2, ÖU.3, ÖU.4, ÖU.7 ve ÖU.8 tüm kazanımlara ulaşmışken, sadece ÖU.6 ve ÖU.9 hiçbir kazanıma ulaşamamıştır. Uygulama grubunda hiçbir kazanıma ulaşamayan ÖU.6 ve ÖU.9 diğer öğrencilere göre okuma becerileri ve öğrenme hızları daha düşük olduğu gibi, okula devamsızlık yapıp ilgili konuların işlendiği derslere katılmamışlardır. Daha sonradan konuyla ilgili bilgi yapraklarını öğretmenlerinden temin etmişler ancak başarı düzeyleri istenilen seviyelere ulaşmamıştır. Öğrencilerin kazanımlarla ilgili olan sorulara verdikleri cevaplar incelendiğinde kazanımların aslında öğrenciler tarafından hiç kazanılamamış değil, sadece istenilen düzeyin altında kısmen kazanıldığ olarak değerlendirilmiştir.

Tablo 7. Destek ve hareket sistemi konusu kazanımlarına ulaşılma düzeylerinin karşılaştırılması

\begin{tabular}{|c|c|c|c|c|c|}
\hline & Öğrenciler & Kazanım 1 & Kazanım 2 & Başarı Yüzdesi (\%) & $\begin{array}{c}\text { Ortalama } \\
\text { Başarı } \\
\text { Yüzdesi (\%) }\end{array}$ \\
\hline 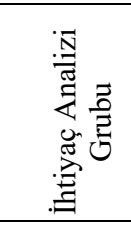 & $\begin{array}{l}\ddot{O}_{\mathrm{i} .1} \\
\ddot{O}_{\mathrm{i} .2} \\
\ddot{O}_{\mathrm{i} .3} \\
\ddot{O}_{\mathrm{i} .4} \\
\ddot{O}_{\mathrm{i} .5} \\
\ddot{O}_{\mathrm{i} .6}\end{array}$ & $\begin{array}{l}+ \\
- \\
- \\
+ \\
- \\
-\end{array}$ & $\begin{array}{l}- \\
- \\
- \\
+ \\
- \\
-\end{array}$ & $\begin{array}{c}50 \\
0 \\
0 \\
100 \\
0 \\
0 \\
\end{array}$ & 25 \\
\hline Başarı Yi & & 33 & 17 & & \\
\hline 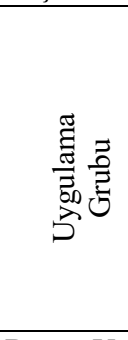 & $\begin{array}{l}\ddot{O}_{\mathrm{U} .1} \\
\ddot{\mathrm{O}}_{\mathrm{U} .2} \\
\ddot{\mathrm{O}}_{\mathrm{U} .3} \\
\ddot{\mathrm{O}}_{\mathrm{U} .4} \\
\ddot{\mathrm{O}}_{\mathrm{U} .5} \\
\ddot{\mathrm{O}}_{\mathrm{U} .6} \\
\ddot{\mathrm{O}}_{\mathrm{U} .7} \\
\ddot{\mathrm{O}}_{\mathrm{U} .8} \\
\ddot{\mathrm{O}}_{\mathrm{U} .9}\end{array}$ & $\begin{array}{l}+ \\
+ \\
+ \\
+ \\
+ \\
- \\
+ \\
+ \\
- \\
\end{array}$ & $\begin{array}{l}- \\
+ \\
+ \\
+ \\
- \\
- \\
+ \\
+ \\
- \\
\end{array}$ & $\begin{array}{c}50 \\
100 \\
100 \\
100 \\
50 \\
0 \\
100 \\
100 \\
0 \\
\end{array}$ & 67 \\
\hline Başarı Yi & & 78 & 56 & & \\
\hline
\end{tabular}

*Kazanım kazanılmış (+), kazanım kazanılmamış ya da kısmen kazanılmış (-)

\section{Sonuç ve Tartışma}

Yapılan çalışmada, GEÖ'in “Destek ve Hareket Sistemi” konusundaki temel kavramları anlama düzeyleri belirlenmiş, fen öğrenimi konusunda yaşadıkları sıkıntılar ve bireysel öğrenme ihtiyaçları ortaya çıkarılmıştır. Ardından GEÖ’in ihtiyaçlarını giderecek ve kavramsal öğrenmeyi gerçekleştirecek bir öğretim modeli tasarlanmış ve uygulanmıştır. Son olarak uygulanan tasarım modelinin; kullanışlılığı, uygulanabilirliği ve kavram öğrenimine olan katkıları değerlendirilmiştir.

İhtiyaç analizi kapsamında yapılan görüşmeler ve sınıf içi gözlemler neticesinde öğrencilerin bireysel ihtiyaçlarına uygun ve görme dışındaki duyularına da hitap edebilen ders materyalleri kullanılarak kavramların mümkün olduğunca somutlaştırılmasına ihtiyaç duyulduğu belirlenmiştir. Benzer şekilde GEÖ'in fen derslerini, genellikle görme duyusu hedef alınarak işlenmesi ve güç/soyut kavramlar barındırması nedeniyle zor bir ders olarak nitelendirdiği, bu yüzden görmenin yanında diğer duyuların kullanımını sağlayacak eğitimsel/çevresel uyarlamalara ihtiyaç duyulduğu çeşitli araştırmalarda da vurgulanmıştır (Dion et al., 2000; Ediyanto \& Kawai, 2019; Fraser \& Maguvhe, 2008; Sözbilir, 2016). Öğrencilerin "Destek ve Hareket Sistemi" konusuna ait kavramları öğrenmede zorlanmalarının nedeni olarak; basılı kaynaklarda yer alan metin ve şekillerin çok küçük olması, Braille kaynakların az olması ve dokunsal materyallerin 
bireysel ihtiyaçlara uygun ve yeterli sayıda olmamasından kaynaklandığı düşünülmektedir. Halbuki, GEÖ’e fen kavramlarının öğretiminde öğrencilerin görme düzeyleri ve bireysel öğrenme ihtiyaçları dikkate alınarak az gören öğrenciler için arta kalan görmelerini kullanabilecekleri etkinlikler ve canlı/zıt renkler içeren materyaller, kör öğrenciler içinse görme dışındaki duyularını kullanabilecekleri etkinlik ve materyaller tasarlandığında, ayrıca işitsel/dokunsal araçlardan ve yardımcı teknolojilerden yararlanıldığında öğrencilerin kavramsal öğrenmeleri geliştirilebilmektedir (Gupta \& Singh, 1998; Lunsford \& Bargerhuff, 2006; Sözbilir, 2016; Supalo et al., 2008; Willings, 2020; Yaz1c1 \& Sözbilir, 2020).

"Destek ve Hareket Sistemi" konusunun GEÖ'e öğretimi amaciyla materyal ve etkinlikler geliştirilirken öğrencilerin bireysel ihtiyaçları dikkate alınarak kör ve az gören öğrencilere yönelik çeşitli uyarlamalar yapılmıştır. Kör öğrencilere yönelik hazırlanan materyallerde öğrencilerin görme dışındaki duyularını kullanarak bilgi edinebilmeleri sağlanmış, az gören öğrencilere ise mevcut görmelerinden en iyi şekilde yararlanabilecekleri canlı ve zıt renklerden oluşan materyaller kullandırılmıştır. Ayrıca körler için hazırlanan bilgi yapraklarındaki metinler Braille olarak basılmış, çizim ve şemalar mümkün olduğunca sadeleştirilerek kabartılmıştır. Bilgi yapraklarında yer alan tablolar ise doğrudan Braille baskı almak yerine, kör öğrenciler tarafından daha kolay anlamlandırılabilmesi için önce düz metine çevrilmiş, ardından Braille baskıları alınmıştır. Az gören öğrenciler içinse tablo ve metinler büyük punto baskı alınırken, çizim/şema içeren basılı materyaller mümkün olduğunca büyük ölçekli ve canl1/zıt renkler kullanılarak hazırlanmıştır. Kavram öğretimi sürecinde kör öğrencilere yönelik tasarlanan materyallerden öncelikle iki boyutlu düzlem üzerinde yer alan kabartma çizimler, ardından bu çizimlere ait 3D modeller kullandırılmıştır. Son olarak da gerçek nesnelerden yararlanılmıştır. Böylece en az ayrıntı olan materyallerden en fazla ayrıntılı olanlarına doğru bir hiyerarşi takip edilmiştir. Ancak bazı öğrencilerin kokulara aşırı duyarlı olması sebebiyle gerçek kemik organlarından rahatsız olmuş ve incelemek istememişlerdir. Bu tür durumlar için gerçek nesnelerin yerine 3D modellerin kullanılmasının daha uygun olacağı düşünülmektedir.

Etkinlik/deney yoluyla öğrencileri konu üzerinde düşündürmek, başka konularla ilgi kurmalarını sağlamak ve araştırma/sorgulama becerisi kazandırmak, kavram öğretiminde oldukça önemlidir (Saygın vd., 2006). Çalışmada tasarlanan etkinlik ve materyallerin mümkün olduğunca tek bir kavram ya da beceriye yönelik olmasına, geçmiş konularla ilişki kurmaya imkân tanımasına ve görme dışındaki diğer duyuları da hedef alan dokunsal, işitsel vb. uyaranlar içermesine özen gösterilmiştir. Bu sayede soyut kavramların mümkün olduğunca somutlaştırılmasına ve kavramsal öğrenmenin geliştirilmesine katkı sağlanmıştır. Nitekim bu tasarım biçimi birçok çalışmada da tavsiye edilmiş ve kullanılmış, sonucunda önemli başarılar elde edilmiştir (Boyd-Kimball, 2012; Harshman et al., 2013; Micklos-Lewis \& Bodner, 2013; Poon \& Ovadia, 2008; Sözbilir vd., 2018; Supalo, 2005).

Çalışma sonucunda uygulama grubu öğrencileri, ihtiyaç analizi grubu öğrencilerine göre görüşme sorularına daha yüksek oranda doğru cevap vermiş, uygulama grubunda her bir görüşme sorusuna verilen doğru cevap yüzdesi ihtiyaç analizi grubuna göre gözle görülür derecede yüksek çıkmıştır. Kullanılan materyallerin, soyut olan kavramları somutlaştırarak dersi oldukça ilgi çekici ve eğlenceli hale getirdiği, Destek ve Hareket sistemi kavramlarının öğrenilmesine olumlu katkılar sağladığı görülmüş̧ür. Sonuç olarak; görme duyusunda yaşanan yetersizliğe rağmen, kullanılan öğretim materyal ve etkinliklerinde öğrencilerin bireysel ihtiyaç ve yetersizlik düzeylerine uygun çeşitli uyarlamalar yapıldığı takdirde öğrenme sürecinde yaşanan birçok olumsuzluğun giderilebileceği, kavramların öğrenciler tarafindan etkili şekilde öğrenilebileceği görülmüştür.

Alanyazında GEÖ'ye yönelik fen öğretimi alanında yapılan çalışmaların az sayıda ve küçük çaplı olduğu görülmüştür. Bu nedenle GEÖ’ye yönelik fen öğretiminin beklenen kalite düzeyine ulaşabilmesi için farklı konularda da daha fazla sayıda ve nitelikte çalışmalar yapılmalı, özellikle uygulamaya yönelik somut verilerin elde edilmesine odaklanılmalıdır. Bu kapsamda yapılacak çalışmalarda öncelikle öğrencilerin yetersizlik düzeyleri ve bireysel öğrenme ihtiyaçları tespit edilerek öğretim bu ihtiyaçlar üzerine tasarlanmalıdır. Bu nedenle GEÖ'nün çeşitli fen konularında sahip oldukları bilgi eksiklikleri ve kavram yanılgılarını belirlemeye yönelik çalışmalara da ihtiyaç duyulmaktadır. Böylece elde edilen veriler yapılacak tasarım çalışmalarında da kullanılarak daha nitelikli ve kullanışlı öğretim tasarımları oluşturulabilecektir. 


\section{Kaynakça / References}

Akaydın G., Güler, M. H., \& Mülayim, H. (2000). Liselerimizin laboratuvar araç ve gereçleri bakımından durumu. Hacettepe Üniversitesi Ĕ̈itim Fakültesi Dergisi, 19, 1-4.

Anderson, L. W., \& Krathwohl, D. R. (2014). Öğrenme, öğretim ve değerlendirme ile ilgili bir sınıflama: Bloom'un eğitimin hedefleri ile ilgili sınıflamasının güncelleştirilmiş biçimi (Kısaltılmış 2. baskı), (Çev. D. A. Özçelik). Ankara: Pegem.

Aydın, G., \& Balım, A. G. (2009). Students' misconceptions about the subjects in the unit "The systems in our body". Procedia Social and Behavioral Sciences, 1, 2258-2263.

Bahar, M. (2002). Students' learning difficulties in biology: Reasons and solutions. Kastamonu Eğitim Fakültesi Dergisi, 10(1), 7382.

Bailey, B. R., \& Wning, J. D. (1994). Using visual accents to enhance attending to communication symbols for students with severe multiple disabilities. Re:View, 26(3), 101-118.

Boyd-Kimball, D. (2012). Adaptive instructional aids for teaching a blind student in a nonmajors college chemistry course. Journal of Chemical Education, 89(11), 1395-1399.

Cavkaytar, A., \& Diken, İ. (2012). Özel eğitim 1: Özel eğitim ve özel ĕgitim gerektirenler (1. bask1). Ankara: Vize Basın Yayın.

Cooperman, S. (1980). Biology for the visually impaired student. The American Biology Teacher, 42(5), $293-304$.

Çepni S., Akdeniz A. R., \& Ayas A. (1995). Fen bilimleri eğitiminde laboratuvarların yeri ve önemi (III), Ülkemizde laboratuvarın kullanımı ve bazı öneriler. Çă̆daş Ĕ̆itim, 206, 24-28.

Dion, M., Hoffmann, K., \& Matter, A. (2000). Teacher's manual for adapting science experiments for blind and visually impaired students. Access: http://www.perkinselearning.org/sites/elearning.perkinsdev1.org/files/teachers-manual.pdf

Ediyanto, E., \& Kawai, N. (2019). Science learning for students with visually impaired: A literature review. Journal of Physics: Conference Series, 1227(1). doi:10.1088/1742-6596/1227/1/012035

Erten, S. (1993). Biyoloji laboratuvarlarının önemi ve laboratuvarlarda karşılaşılan problemler. Hacettepe Üniversitesi Ĕ̈itim Fakültesi Dergisi, 9, 315-330.

Fraser, W. J., \& Maguvhe, M. O. (2008). Teaching life sciences to blind and visually impaired learners. Journal of Biological Education, 42(2), 84-89.

Gupta, H. O., \& Singh, R. (1998). Low-cost science teaching equipment for visually impaired children. Journal of Chemical Education, 75(5), 610-612.

Halim, A. S., Finkenstaedt-Quinn, S. A., Olsen, L. J., Gere, A. R., \& Shultz, G. V. (2018). Identifying and remediating student misconceptions in introductory biology via writing-to-learn assignments and peer review. CBE-Life Sciences Education, 17(2), 28-37.

Harshman, J., Bretz, S. L., \& Yezierski, E. (2013). Seeing chemistry through the eyes of the blind: A case study examining multiple gas law representations. Journal of Chemical Education, 90, 710-716.

Hiemenz, P. C., \& Pfeiffer, E. (1972). A general chemistry experiment for the blind. Journal of Chemical Education, 49(4), 263265.

Kaya, E. (2001). Ortaöğretimde biyoloji öğretiminin yapı ve sorunlart-Erzurum örneği (Yayınlanmamış doktora tezi). Atatürk Üniversitesi, Erzurum.

Kelly, A. E. (2003). The role of design in educational research. Educational Researcher, 32(1), 3-4.

Kuzu, A., Çankaya S., \& Mısırlı, Z. A. (2011). Tasarım tabanlı araştırma ve öğrenme ortamlarının tasarımı ve geliştirilmesinde kullanımı. Anadolu Journal of Educational Sciences International, 1(1), 19-35.

Lunsford, S. K., \& Bargerhuff, M. E. (2006). A project to make the laboratory more accessible to students with disabilities. Journal of Chemical Education, 83(3). doi:10.1021/ed083p407 
Mann, C. (2006). Educational placement options for blind and visually impaired students: A literature review (SESRC Document No. 06-01-2202). Washington, DC: Washington State Institute for Public Policy.

Micklos-Lewis, A. L., \& Bodner, G. M. (2013). Chemical reactions: What understanding do students with blindness develop? Chemistry Education Research and Practice, 14, 625-636.

Neely, M. B. (2007). Using technology and other assistive strategies to aid students with disabilities in performing chemistry lab tasks. Journal of Chemical Education, 84(10), 1699-1701.

Özay-Köse, E., \& Gül, Ş. (2016). Prospective biology teachers' understanding of scientific models. Uşak University Journal of Social Sciences, 9(3), 162-180.

Öztaş, H., \& Özay, E. (2004). Biyoloji öğretmenlerinin biyoloji öğretiminde karşılaştıkları sorunlar (Erzurum örneği). Kastamonu Eğitim Dergisi, 12(1), 69-76.

Patton, M. Q. (2002). Qualitative research \& evaluation methods (3rd ed.). Thousand Oaks, CA: Sage.

Poon, T., \& Ovadia, R. (2008). Using tactile learning aids for students with visual impairments in a first-semester organic chemistry course. Journal of Chemical Education, 82(2), 240-242.

Ratliff, J. L. (1997). Chemistry for the visually impaired. Journal of Chemical Education, 74(6), 710-711.

Saygın, Ö., Atılboz, N. G., \& Salman, S. (2006). Yapılandırmacı öğretim yaklaşımının biyoloji dersi konularını öğrenme başarısı üzerine etkisi: Canlılığın temel birimi-Hücre. Gazi Eğitim Fakültesi Dergisi, 26(1), 51-64.

Silberman, R. K., \& Erin, J. (2007). Visual impairments. In. E. L. Meyen \& Y. N. Bui (Eds.), Exceptional children in today's school: What teachers need to know (4th ed.) (pp.283-306). Denver, CO: Love Publishing Co.

Sözbilir, M. (2016). Practical work in science with visually impaired students. In I. Eilks, S. Markic, \& B. Ralle (Eds.), Science education research and practical work (pp. 169-179). Aachen: Shaker Verlag.

Sözbilir, M., Gül, Ş., Okcu, B., Yazıcı, F., Kızılaslan, A., Zorluoğlu, S. L., \& Atila, G. (2015). Görme yetersizliği olan öğrencilere yönelik fen eğitimi araştırmalarında eğilimler. Abant İzet Baysal Üniversitesi Ĕ̆itim Fakültesi Dergisi, 15(1), $218-241$.

Sözbilir, M., Okcu, B., Gül, Ş., Zorluoğlu, L. S., Kızılaslan, A., \& Yazıcı, F. (2016). A study of needs analysis towards effective science instruction for 6th grade visually impaired students. International Conference Effective Leadership and Management in Inclusive Schools: Teacher Training and Vocational Education, Arts and Sports, Konya, Turkey.

Sözbilir, M., Yazıcı, F., \& Gül, Ş. (2018). 6. sınıf görme engelli öğrencilere "kurbağalarda ve kelebeklerde başkalaşım” konusunun öğretimine yönelik materyal tasarımı. 27. Uluslararası Ĕ̆itim Bilimleri Kongresi, Antalya, Türkiye.

Supalo, C. (2005). Techniques to enhance instructors' teaching effectiveness with chemistry students who are blind or visually impaired. Journal of Chemical Education, 82(10), 1513-1518.

Supalo, C. A., Mallouk, T. E., Rankel, L., Amorosi, C., \& Graybill, C. M. (2008). Low-cost laboratory adaptations for precollege students who are blind or visually impaired. Journal of Chemical Education, 85(2), 243-247.

Şafak, P. (2010). Genel eğitim okullarında özel gereksinimi olan öğrenciler ve özel eğitim. A. G. Akçamete (Ed.), Görme yetersizliği olan çocukların eğitimi (3. baskı) içinde (ss. 397-436). Ankara: Kök Yayıncılık.

Şafak, P., Çakmak, S., Kan, A., \& O’Dwyer, P. A. (2013). Gazi işlevsel görme değerlendirme aracı ile az gören öğrencilerin görme becerilerinin değerlendirilmesi. TÜBİTAK Projesi Sonuç Raporu (Proje No: 111K549).

Wang, F., \& Hannafin, M. J. (2005). Design-based research and technology-enhanced learning environments. Educational Technology Research and Development, 53(4), 5-23.

Willings, C. (2020). Material adaptations. Access: https://www.teachingvisuallyimpaired.com/material-adaptations.html

Yazıcı, F., \& Sözbilir, M. (2020). Görme engelli altıncı sınıf öğrencilerine hücre konusunun öğretimi. Eğitim ve Bilim, 45(204), 227-250.

Zorluoğlu, S. L., \& Sözbilir, M. (2017). Görme yetersizliği olan öğrencilerin öğrenmelerini destekleyici ihtiyaçlar. Trakya Üniversitesi Ĕgitim Fakültesi Dergisi, 7(2), 659-682. 